\title{
ARTYKUŁY
}

Klio. Czasopismo poświęcone dziejom Polski i powszechnym

PL ISSN 1643-8191, t. 25 (2)/2013, s. 81-117

(c) $\odot$ DOI: http://dx.doi.org/10.12775/KLIO.2013.017

\section{TOMASZ CiEsIELSKI}

(Opole)

\section{Potencjat militarny Rzeczypospolitej Obojga Narodów w okresie polskiej wojny sukcesyjnej 1733-1735. Wybrane aspekty}

\section{Stan badań}

Dotencjał bojowy wojsk Rzeczypospolitej, zwłaszcza armii regularnej, przebieg działań bojowych w okresie polskiej wojny sukcesyjnej - zagadnienia te długo pozostawały na uboczu zainteresowań historyków polskich ${ }^{1}$. Przez wiele lat podstawowym źródłem informacji na ten temat było

${ }^{1}$ Celowo pomijam w rozważania prace niemiecko-, anglo- i przede wszystkim rosyjskojęzyczne, gdyż potencjał i działania wojsk polsko-litewskich omówione zostały w nich ogólnikowo. Najważniejsze prace to niewątpliwie wydawnictwa źródłowe z Amaka Гданска фельдмаршаломь Минихомь 1734 года. Сборник релячий графа Миниха, wуд. А. Ф. Масловский, Москва 1888 na czele, a także opracowania, wśród których wciąż niezastąpiona pozostaje wydana jeszcze w pierwszej ćwierci XIX w. praca А. П. Бутурлин, Военная исторія походовь Россіянь вь XV III стольтіи, Ч. 3: Заключанощая вь себъ описаніе Польской войны сь 1733-го nо 1735-й год, Санкт Петербург 1823. Ze względu na częstość 
opracowanie Stefana Truchima² ${ }^{2}$ Poszczególne kampanie i epizody tej wojny omówili Kazimierz Jarchowski ${ }^{3}$, Alfons Wodziński i Edmund Cieślak (oblężenie Gdańska) ${ }^{5}$, a udział w działaniach zbrojnych dwóch Tarłów - Miłosz Gembarzewski ${ }^{6}$ i Leopold Hubert ${ }^{7}$. W ostatnich latach ukazało się drukiem kilka artykułów poświęconych zaangażowaniu społeczeństwa szlacheckiego i poszczególnym kampaniom wojny pióra Stanisława Achremczyka ${ }^{8}$, Adama Liska ${ }^{9}$ oraz autora niniejszego artykułu ${ }^{10}$.

cytowań wspomnieć należy o monografii J. L. Sutton, The King's Honor and the King's Cardinal. The War of the Polish Succesion, Lexington 1980, a z najnowszych prac obszerny artykuł autorstwa białoruskiego historyka Andrieja Macuka: А. Мацук, Войска як інструмент усталявання јлады Аугуста III у BK 1 y 1733-1735 г., „Беларускі Гістарычны АгляА" 2009, t. 15, s. 329-363.

2 S. Truchim, Konfederacja dzikowska, Poznań 1921.

${ }^{3}$ K. Jarochowski, Oblężenie Gdańska w roku 1734, Szkic historyczny, [w:] idem, Z czasów saskich spraw wewnętrznych, polityki i wojny, Poznań 1886.

${ }^{4}$ A. Wodziński, Gdańsk za czasów Stanistawa Leszczyńskiego 1704-1709, 1733-1734, Kraków 1929; idem, Oblężenie Gdańska w roku 1733-1734, „Rocznik Gdański” 1935/1936, t. 9/10.

${ }^{5}$ E. Cieślak, W obronie tronu króla Stanistawa Leszczyńskiego, Gdańsk 1986.

${ }^{6}$ M. Gembarzewski, Jan Tarto: Pierwszy powstaniec polski, Kraków 1935.

${ }^{7}$ L. Hubert, Adam Tarto, wojewoda lubelski, [w:] idem, Pamiętniki historyczne, Warszawa 1861, t. 1, s. 165-194.

8 S. Achremczyk, Warmia wobec wydarzeń z lat 1733-1736, „Komunikaty Mazursko-Warmińskie” 1985, z. 1-2, s. 21-49.

9 A. Lisek, Obóz stanistawowski na Litwie w okresie wojny o tron polski do zawiazania konfederacji generalnej wileńskiej (1733-1734), „Studia Historyczne” 2007, R. L, z. 2 (198), s. 129-139.

${ }_{10}$ T. Ciesielski, Agresja rosyjska na Polskę 1733-1735. Walki na Ukrainie, Podolu $i$ Wotyniu, [w:] Trudne sasiedztwo. Studia z dziejów stosunków polsko-rosyjsko-ukraińskich w XVI-XX wieku, red. A. Szczepaniak, Toruń 2007, s. 100-130; idem, W obronie Gdańska - dziatania wojsk polskich na Pomorzu i Kujawach 1733-1734, „Studia Historyczno-Wojskowe”, t. 2, red. P. Gawron, K. Bobiatyński, M. Nagielski, Warszawa 2008, s. 177-195; idem, Dziatania zbrojne $w$ rejonie Krakowa $w$ trakcie polskiej wojny sukcesyjnej 1733-1735, „Studia Historyczne” 2009, R. LII, z. 3-4, s. 203-222; idem, Узброеныл сіль ВКА падчас вайны за польскую спадчвгну 1733-1735 г2., „АRCHE”, червень 2011, nr 6 (105), s. 246-259; idem, Баявыя дзеянні на тэрыторыі Вялікага Княства Аітоускага падчас вайны за польскую спадивгну у 1733-1735 г2., „АRCHЕ”, чэрвень 2012, nr 6 (117): Вайсковая гісторыля Вялікага Княства Аітоускага, s. 347-371. 
W niniejszym studium omówione zostaną tylko siły zbrojne i formacje, które przynajmniej potencjalnie mogły zostać wykorzystane w działaniach polowych: oddziały piechoty, jazdy i artylerii, niezależnie od ich statusu „własnościowego”. Pominięty został ważny element obronności kraju, jakim były fortece, które w kontekście polskiej wojny sukcesyjnej zasługują na oddzielny artykuł. Przygotowania do wojny w najważniejszej twierdzy państwowej, Kamieńcu Podolskim, zostały przy tym obszernie (co nie znaczy wyczerpująco) omówione w książce Renaty Król-Mazur ${ }^{11}$ oraz artykułach Adama Perłakowskiego ${ }^{12}$ i Adama Liska ${ }^{13}$. Ten ostatni przedstawił też przygotowania do wojny i sytuację w Zamościu, ale nie pokusił się nawet o ogólnikowe scharakteryzowanie potencjału militarnego twierdzy i milicji ordynackiej $^{14}$.

\section{Budżety wojskowe i komputy armii Rzeczypospolitej Obojga Narodów 1717-1733}

Oddziały państwowe, stałe armie, koronnai Wielkiego Księstwa Litewskiego, utrzymywane były na mocy uchwał skarbowo-wojskowych sejmu niemego 1717 roku. W trakcie poprzedzających go rokowań warszawskich, na przełomie 1716 i 1717 r. określono budżety obu armii, uwzględniając trudną sytuację gospodarczą kraju u schyłku wielkiej wojny północnej, konflikt na linii król - szlachta, związany z realnymi czy też rzekomymi planami

${ }^{11}$ R. Król-Mazur, Miasto trzech nacji. Studia z dziejów Kamieńca Podolskiego w XVIII wieku, Kraków 2008, s. 117-125, 138.

12 A. Perłakowski, Nad granica z Porta Ottomańską. Twierdza kamieniecka w latach 1733-1735, [w:] Staropolski oglad świata. Rzeczpospolita między okcydentalizmem a orientalizacja, t. 1: Przestrzeń kontaktów, red. F. Wolański i R. Kołodziej, Toruń 2009, s. 112-129 .

13 A. Lisek, Rola Kamieńca Podolskiego dla obozu stanistawowskiego w województwie podolskim w latach 1733-1736, „Rocznik Przemyski” 2005, t. XLI, z. 4, Historia, s. 3-31.

${ }^{14}$ Idem, Zamość w latach 1733-1736. Zarys problematyki, „Rocznik Przemyski” 2008, t. XLIV, z. 4, Historia, s. 33-44. 
absolutystycznymi Augusta II, a także kierując się pragnieniem nieprowokowania sąsiadów ${ }^{15}$.

Budżet wojskowy dla Korony został w 1717 r. określony na poziomie $5,425 \mathrm{mln} \mathrm{zł}^{16}$. Pewną zmienną stanowiły początkowo środki przeznaczone na utrzymanie artylerii koronnej, które pochodziły z ustanowionej jeszcze w 1637 r. drugiej kwarty, tzw. „nowej” lub „artylerycznej”. W latach 1717-1719 wpływy z niej wahały się między 112851 zł a 125820 zł, a w latach 1720-1735 od 116703 zł do 117433 zł $^{17}$. Od września 1727 r. budżet wojskowy zasilił podatek na piechotę łanową, opłacany z osiadłych łanów wybranieckich w zamian za ich wieczyste zwolnienie z obowiązku wystawiania żołnierzy na wyprawę wojenną. Wysokość świadczenia ustalono na 100 zł z łanu rocznie, płatnych w dwóch ratach: marcowej i wrześniowej ${ }^{18}$. Według najbardziej optymistycznych szacunków miało ono przynieść w skali roku nawet $6 \mathrm{mln} \mathrm{zł}^{19}$, ale po rewizji przeprowadzonej w 1727 roku i na początku 1728 r. wykazała, że w Koronie pozostało tylko 1 177,25 osiadłych łanów wybranieckich, co oznaczało powiększenie rocznego budżetu wojskowego tylko o 117725 zł. Do 1730 r. dzięki przejrzeniu „ksiąg” i lustracji „odkryto” jeszcze dodatkowych 200 łanów, ale wysokość wydatków na cele wojskowe w następnych latach nie wskazuje,

15 Uchwały skarbowo-wojskowe Sejmu Niemego: Volumina Legum, wyd. J. Ohryzko, Petersburg 1859 (dalej VL), t. VI, s. 137-143, 146, 150-157, 164-201. Literatura: M. Nycz, Geneza reform skarbowych sejmu niemego. (Studium z dziejów skarbowo-wojskowych z lat 1697-1717), Poznań 1938, s. 189-265; J. Wimmer, Wojsko Rzeczypospolitej $w$ dobie wojny pótnocnej, Warszawa 1956, s. 430-487; M. Drozdowski, Dziatalność budżetowa Sejmu w czasach saskich, „Roczniki Dziejów Społecznych i Gospodarczych” 1977, t. XXXVIII, s. 128-134; J. Gierowski, "Opisanie” urzędów centralnych przez konfederatów tarnogrodzkich, [w:] O naprawe Rzeczypospolitej XVII-XVIII. Prace ofiarowane Wtadystawowi Czaplinskiemu w 60 rocznice urodzin, Warszawa 1965, s. 193-211; J. Staszewski, August II Mocny, Wrocław i in. 1998, s. 197-199; T. Ciesielski, Armia koronna w czasach Augusta III, Warszawa 2009, s. 19 i nast.

${ }^{16}$ M. Nycz, op. cit., s. 212; T. Ciesielski, Armia koronna..., s. 24.

17 Archiwum Główne Akt Dawnych w Warszawie (dalej: AGAD), Archiwum Skarbu Koronnego (dalej: ASK), dz. II, 79-81; T. Ciesielski, Armia koronna, s. 20, 51.

${ }^{18} \mathrm{VL}, \mathrm{t}$. VI, s. 212.

19 Sächsisches Hauptstaatsarchiv, Dresden (dalej: SHD), Geheimes Kabinett (dalej: GK), loc. 3639/10; AGAD, Archiwum Rodzinne Poniatowskich, 360; T. Ciesielski, Armia koronna, s. 20-21. 
aby zaowocowało to powiększeniem budżetu „łanowego" (a tym samym i militarnego) o $20000 \mathrm{zł}^{20}$. Dlatego też należy przyjąć, że pod koniec trzeciej dekady XVIII w. koronny budżet wojskowy powiększył się jedynie do niespełna 5543 tys. zł. Ponadto między 1717 a 1733 rokiem rady senatu przyznały na cele wojskowo-porządkowe 364000 zł, z tego 180000 zł na refortyfikację Kamieńca i 80000 zł na artylerię ${ }^{21}$.

W przypadku Wielkiego Księstwa Litewskiego można mówić wręcz o rewolucyjnych zmianach, a najważniejszą było ustanowienie stałego budżetu wojskowego. Składał się on z trzech części. Pierwszą stanowiły środki przeznaczone na utrzymanie oddziałów piechoty i jazdy komputowej wynoszące 2046000 zł. Drugą - 20000 zł, będących budżetem trybunalskiej chorągwi piechoty węgierskiej. Trzecia to budżet artylerii, który Michał Nycz oceniał na 69000 zł, w tym 54000 zł tytułem kwarty oraz 15000 zł $\mathrm{z}$ „dóbr artyllerycznych” ${ }^{22}$. W rzeczywistości środki przeznaczone na utrzymanie artylerii były znacznie niższe, a pochodziły z dwóch źródeł „przychodów”. Pierwszym była kwarta przynosząca 12 000-12 700 zł. Drugim dochody z tzw. „dóbr artyllerycznych”, czyli z podarowanych artylerii litewskiej w XVII w.: jurydyki antokolskiej (z folwarkiem Wierszupie), starostwa Lipniszki, klucza Gieranony oraz folwarków Remirów i Nosiewicze. Wpływy z nich w latach 1720-1724 wynosity od 9000 do 14000 zł rocznie ${ }^{23}$. Budżet wojskowy Wielkiego Księstwa wahał się więc od ok. 2087000 zł (jak w 1721 r.) do ok. 2092500 zł.

Oba budżety pozwoliły na utworzenie niewielkich armii, które „na papierze" liczyły ok. 25000 stawek żołdowych. W trzeciej dekadzie osiem-

${ }^{20}$ VL, t. VI, s. 212-213; AGAD, Archiwum Publiczne Potockich (dalej: APPot), 168, s. 557; Центральный Аержавний історичний архів України, м. Аьвів (ЦАІАУ А), fond 181, op. 2, 2310, k. 8-9, 2766, s. 9-10 oraz 2775, k. 4; J. M. Podoski do J. Tarły, Rusinowa 1 VII 1730, Центральный державний історичний архів України, м. Кїив (ЦАIAУK), fond 254, op. 1, 499, k. 2-3; T. Ciesielski, Armia koronna, s. 21.

${ }^{21}$ AGAD, ASK, dz. II, 78-80; M. Markiewicz, Rady senatorskie Augusta II (1697-1733), Wrocław 1988, s. 90, 93.

${ }^{22}$ M. Nycz, op. cit., s. 214. Za Nyczem taką wysokość budżetu artylerii litewskiej przyjął J. Wimmer, op. cit., s. 434.

${ }^{23}$ Lietuvos Valstybès Istorijos Archyvas, Vilnius (dalej: LVIA), SA, 2427. W drugiej dekadzie XVIII w. kwarta przynosiła 11234 zł i 22,5 gr. rocznie: Biblioteka im. Książąt Czartoryskich w Krakowie (dalej: BCz), 2654, s. 28. 
nastego stulecia nie odbiegały one jeszcze rażąco swoją wielkością od wojsk innych krajów europejskich, ale tylko pod względem ilości stawek żołdowych, a nie realnie pełniących służbę żołnierzy.

Armia koronna, po zwiększeniu jeszcze w okresie od zimy do wiosny 1717 r. ilości porcji w piechocie (dzięki zmniejszeniu kwoty przeznaczonej na opłacenie jednej stawki żołnierskiej z 200 zł do 189 zł w skali roku) oraz sformowaniu w latach 1729-1730 siódmego regimentu pieszego, tzw. łanowego, rozbudowana została najpierw do 18 442, a później do ponad 19000 stawek żołdowych. Z tego 6000 przypadało na jazdę narodowego zaciągu, 400 na piechotę węgierską i janczarską, a pozostałe na autorament cudzoziemski. Pierwsza podzielona była początkowo na 107 choragwi: 16 husarskich, 77 pancernych, 14 jazdy lekkiej. Po rozdzieleniu dużych jednostek tej ostatniej, wchodzących w skład pułku królewskiego, na mniejsze chorągwie, ich liczba wrosła nawet do 22 . W skali całej jazdy narodowego zaciągu oznaczało to powiększenie do 114 chorągwi, wśród których zdecydowanie dominowały liczebnie oddziały małe 25-55-konne (tylko 8-10 większych 75-110-konnych). System „ślepych porcji” nie powodował w nich wielkich ubytków kadrowych, gdyż sprowadzał się do 5-10 porcji pańskich i rotmistrzowskich. W rezultacie z 6000 porcji utrzymywano ok. 5550 oficerów, towarzyszy, pocztowych i sygnalistów. Nieco większe były potrącenia w piechocie węgierskiej i janczarskiej - w trzech chorągwiach służyło ok. 350 żołnierzy. Autorament cudzoziemski podzielony był na 7 regimentów dragońskich (4 000 stawek) oraz początkowo 6, a następnie 7 regimentów piechoty (8 136-8 802). Ich stany osobowe znacząco odbiegały od etatowych za sprawą „ślepych porcji” i potrąceń na cele bezosobowe, na które łącznie odchodziło początkowo ok. 40\%, a później jeszcze większy odsetek stawek żołdowych. W rezultacie liczebność tego zaciągu wyrażona w etatach wynosiła w latach 1717-1733 nieco ponad 7100 żołnierzy. W sumie w armii koronnej służyło przeciętnie ok. 13000 żołnierzy $^{24}$. Około $40 \% \mathrm{z}$ nich nie było przy tym przygotowanych do udziału

${ }^{24}$ T. Ciesielski, Armia koronna, s. 59-109, 203-215, 251-340; idem, Jazda koronna $i$ Wielkiego Księstwa Litewskiego autoramentu narodowego armii Rzeczypospolitej Obojga Narodów w latach 1717-1776, [w:] Do szarży marsz, marsz ... Studia z dziejów kawalerii, red. A. Smoliński, Toruń 2010, s. 24-25, 27-28, 34-44. 
w działaniach polowych, gdyż w trakcie pokoju wszystkie oddziały piechoty wykorzystywano jako garnizonowe - pełniły służbę w Elblągu, Toruniu, Poznaniu, Warszawie, Kamieńcu Podolskim, Białej Cerkwi oraz Okopach Świętej Trójcy ${ }^{25}$.

W skład armii Wielkiego Księstwa wchodziły 4 chorągwie piesze z 400 porcjami (ale w rzeczywiści realizowano etat 410-porcjowy), 3 regimenty piesze (1 850 porcji), 4 regimenty dragońskie (1 500 porcji i koni), korpus artylerii z frejkompanią grenadierską (150 stawek) oraz 50-52 chorągwie jazdy narodowego zaciaggu z 2300 stawkami, w tym 6 husarskich (400 stawek), 26 petyhorskich (1200 stawek) i 18-20 lekkich (700 stawek). W litewskiej jeździe narodowego zaciągu „ślepe porcje” pochłaniały więcej stawek niż w koronnej za sprawą lepszego wynagradzania kadry dowódczej i oficerskiej (np. rotmistrzowie pobierali w Wielkim Księstwie 12, a w Koronie 5 porcji, porucznicy odpowiednio 6 i 2). W rezultacie w chorągwiach husarskich, petyhorskich, tatarskich i kozackich służyło do 1700 oficerów, towarzyszy, pocztowych i sygnalistów. W piechocie węgierskiej oraz autoramencie cudzoziemskim skala potrąceń była zbliżona do koronnych. W czterech chorągwiach węgierskich służyło do 350, w trzech regimentach piechoty 1 135-1 200, a w czterech regimentach dragońskich 855-870 żołnierzy. Do tego dochodził korpus artyleryjski z ok. 120 ludźmi. Łącznie w armii Wielkiego Księstwa mogło służyć maksymalnie do 4 150-4 170 żołnierzy $^{26}$.

25 T. Ciesielski, Armia koronna, s. 491-492.

${ }^{26}$ Opracowania dotyczące armii litewskiej czasów saskich: V. Rakutis, Lietuvos kariuomenés organizacija reglamentuojantys dokumentai 1717-1775 m., „Karo archyvas”, t. XVIII, Vilnius 2003, s. 65-121; J. Daujotas, Lietuvos Didžiosios kunigaikštystès karybos problemos Augusto III valdymo laikotarpiu (1733-1763), [w:] Lietuvos valstybe XII-XVIII a., red. Z. Kiaupe, A. Mickevičius, J. Sarcevičiene, Vilnius 1997, s. 549-559; M. J. Lech, Autorament cudzoziemski wojsk Wielkiego Księstwa Litewskiego w epoce saskiej, „Studia i Materiały do Historii Wojskowości” 1961, t. VII, cz. 1, s. 91-112; idem, Jazda autoramentu polskiego wojsk Wielkiego Księstwa Litewskiego w dobie saskiej, „Studia i Materiały do Historii Wojskowości” 1961, t. VII, cz. 2, s. 45-93; idem, Sktad narodowy i spoteczny wojsk Rzeczpospolitej 1717-1762, „Zeszyty Naukowe Uniwersytetu Warszawskiego” 1963, t. 3, s. 102-122; J. Wimmer, op. cit., s. 434, 443-444, 466; M. Nycz, op. cit., s. 214 n.; T. Ciesielski, Узброеньл сіль ВK 1, s. 248-253; idem, Jazda koronna i Wielkiego Księstwa, s. 25-26, 28-30, 34-44. Regulaminy organizacyjne oraz raporty miesięczne o stanie 


\section{Regularne armie Rzeczypospolitej Obojga Narodów w trakcie wojny 1717-1733}

W chwili śmierci Augusta II liczebność państwowych oddziałów polskich i litewskich zapewne niewiele odbiegała od stanu maksymalnego, co w przypadku autoramentu cudzoziemskiego było zasługą zorganizowanego latem 1732 roku na polach mokotowskich kampamentu ${ }^{27}$. Dzięki starannym przygotowaniom do tej rewii, uczestniczące $\mathrm{w}$ niej oddziały polskie i litewskie zostały nie tylko dokompletowane i przeszkolone, ale też wymieniono i uzupełniono wyposażenie. W miarę upływu miesięcy żołnierzy jednak ubywało i do odwrócenia tej tendencji nie przyczynił się wybuch działań wojennych na przełomie lata i jesieni 1733 roku. Dobitnie dowodzi tego przykład regimentu pieszego królewicza z armii koronnej, w którym wiosną 1734 r. zamiast 600-606 było ok. 450 żołnierzy. Oznaczało to brak $25 \%$ ludzi w stosunku do regulaminowego stanu etatowego ${ }^{28}$. W przypadku innych regimentów piechoty ten ubytek mógł być nieco niższy, co sugerują raporty przedstawiające stan garnizonu kamienieckiego ${ }^{29}$. Ale i tak w stacjonujących w tej twierdzy regimentach brakowało ponad $15 \%$ żołnierzy. W dragonii już u progu jesieni 1733 roku w gwardii było jedynie 500 podoficerów i szeregowców, a w pozostałych regimentach od 100 do 180 (w dowodzonym przez płk Jana Bukowskiego z „pełnym kompletem

niektórych oddziałów litewskich autoramentu cudzoziemskiego z lat 1717-1733: LVIA, SA 18581, passim; LVIA, SA 18259, k. 22-23v, 39-43; BCz, 2648, k. 375, 383, 391.

27 O kampamencie oraz związanym z nim dokompletowaniem i doposażeniem regimentów: SHD, GK, loc. 1956/2; loc. 3645/5; „Kurier Polski” 1732, nr 138 i 139; BCz, 2632; J. Bartoszewicz, Kampament w Warszawie 1732 r., „Przegląd Naukowy” 1847, nr 22, s. 667-669; J. Benda, Kampamenty Jana Christiana Mocka, „Muzealnictwo Wojskowe”, t. 2, Warszawa 1964, s. 325-358; J. Wimmer, Historia piechoty polskiej do roku 1864, Warszawa 1978, s. 327.

28 B. Ch. von Münnich do Anny Iwanownej, Pruszcz 15/26 III 1734, Аmaка Гданска, s. 26-27; Archiwum Państwowe w Krakowie (dalej: APKr), Archiwum Podhoreckie (dalej: APodh), II, 363; T. Ciesielski, Armia koronna, s. 317.

${ }^{29}$ APKr, APodh, II, 360, s. 6-7. 
oficerów”) ${ }^{30}$. Tymczasem etat pierwszej przewidywał 629-637, a pozostałych oddziałów 262-268 żołnierzy ${ }^{31}$.

W odniesieniu do koronnego autoramentu cudzoziemskiego można stwierdzić, że w początkowym okresie polskiej wojny sukcesyjnej w służbie było do 5700 oficerów i szeregowców. Podobne, o ile nie większe ubytki występowały niewątpliwie w koronnym zaciągu narodowym oraz całej armii litewskiej, dla których nie zachowały się źródłowe dane liczbowe. Dowodzący w okresie bezkrólewia wojskiem Wielkiego Księstwa regimentarz generalny Michał Serwacy Wiśniowiecki, ostro skrytykowany 27 sierpnia przez Koroniarzy za bezczynność w obliczu przemarszu rosyjskiego korpusu interwencyjnego przez Litwę, twierdził, że dysponował tylko 3 tysiącami słabo przygotowanych do wojny żołnierzy ${ }^{32}$.

Liczebność armii „państwowych” Rzeczypospolitej należy szacować na ok. 15-15,5 tys. ludzi u progu jesieni 1733 roku, a w następnych miesiącach żołnierzy sukcesywnie ubywało. Służyli oni przy tym w wojskach popierających obu rywalizujących ze sobą pretendentów do tronu polsko-litewskiego. Wojna sukcesyjna z lat 1733-1735 miała charakter konfliktu domowego, szczególnie widocznego w Wielkim Księstwie. W Koronie początkowo cała armia regularna stanęła po stronie Stanisława Leszczyńskiego, a za elektorem saskim Fryderykiem Augustem II opowiedzieli się tylko pojedynczy oficerowie (np. pułkownicy Marek Szembek i Bolesław Górecki ${ }^{33}$ ). Dopiero między majem i lipcem 1734 r. do obozu wettyńskiego formalnie przeszły pododdziały komputowe i tzw. nowa gwardia nadworna z załogi Gdańska, regiment pieszy królewicza z Elbląga oraz batalion gwardii pieszej, który poddał się Rosjanom w Brodach. Ze względu na wątpliwości,

${ }^{30}$ Biblioteka Jagiellońska w Krakowie (dalej: BJ), 3605, k. 7-8v, 10v.

31 T. Ciesielski, Armia koronna, s. 280-284.

32 A. Lisek, Litwini na sejmie elekcyjnym w 1733 roku, [w:] Z dziejów XVII i XVIII wieku. Ksiega jubileuszowa ofiarowana Profesorowi Michatowi Komaszyńskiemu, red. J. Kwak, Katowice 1997 s. 151; idem, Postawa Radziwittów w okresie przedostatniego bezkrólewia i w pierwszych miesiacach wojny domowej (1733-1734), [w:] Radziwittowie. Obrazy literackie. Biografie, świadectwa historyczne, red. K. Stępnik, Lublin 2003”, s. 365.

33 H. W. Wilczek do Karola VI, Kraków 10 III 1734, Haus-, Hof- und Staatsarchiv Wien (dalej: HHStA), Polen II, 12, k. 272; T. Ciesielski, Szembek Marek, [w:] Polski stownik biograficzny, t. XLVIII/1 (z. 196), Warszawa - Kraków 2012, s. 100. 
co do wierności służących w nich żołnierzy, oddziały te nie były wykorzystywane w działaniach wojennych. Znikome rezultaty przyniosła też zainicjowana u schyłku lata 1734 r. próba przeciągnięcia na stronę Augusta III innych jednostek wojskowych - zwłaszcza jazdy szlacheckiej pożądanej z powodów innych niż militarne - którą kierował mianowany pierwszym pułkownikiem armii koronnej krajczy koronny Michał Rzewuski ${ }^{34}$.

$\mathrm{Na}$ Litwie do podziału armii doszło jesienią 1733 roku. Część oddziałów dochowało wierności „staremu” regimentarzowi generalnemu M. S. Wiśniowieckiemu, który 8 listopada wydał w Warszawie uniwersał wzywający armię Wielkiego Księstwa do przejścia na stronę Augusta III. Wspomagał go wojewoda nowogródzki Mikołaj Faustyn Radziwiłł, którego Wiśniowiecki powołał na swojego zastępcę i przekazał mu dowództwo nad „dywizją białoruską" ${ }^{35}$. Wspólnymi siłami udało im się przejąć komendę nad częścią jazdy oraz hetmańskimi regimentami autoramentu cudzoziemskiego i chorągwiami straży przedniej, w tym pułkiem dowodzonym przez Jana Kościę ${ }^{36}$. Siłami zbrojnymi drugiej strony konfliktu dowodził strażnik litewski Antoni Aleksander Pociej, któremu Stanisław Leszczyński nadał 18 września 1733 r. odebrany Wiśniowieckiemu urząd regimentarza generalnego wojska Wielkiego Księstwa. Między 20 września i 5 listopada Pociej wydał

${ }^{34}$ Uniwersał Augusta III, Oliwa 29 VII 1734, BCz, 212, s. 165-166; Kriegsarchiv Wien, Alte Feldakten, 425, IX-X 1734; HHStA, Polen II, 13, k. 661-823; Российский Государственный Военно-Историчный Архив, Москва, fond 114, op.1, 30, k. 110v-111; Архив Внешней Помитики Российской Импери, Москва, fond 80, 232, k. 61, 96 oraz 252, k. 31 i nast.; SHD, GK, loc. 3640/11. Listy do T. K. Lubomirskiego, 31 VII, 14, 23, 27 VIII, 10 IX, 22 X, 4 XI 1734, AGAD, APPot, 169, s. 129-135, 159, 322-324, 357-360, 363-364, 390-392, 418. Uniwersał gen. mjr I. Bachmetowa, Rudna 13 VIII 1734, ЦАІАУК, fond 49, op. 1, 1492, k. 16; uniwersał M. Rzewuskiego informujący o objęciu komendy nad wojskiem, pod Oliwą 3 VIII 1734, ЦАІАУK, fond 49, op. 1, 1521, k. 37, a także jego list do J. Tarły przesłany przez kpt. F. Idzikowskiego, ЦАІАУК, fond 254, op. 1, 531, k. 11. T. Ciesielski, Armia koronna, s. 494-495.

35 APKr, Archiwum Młynowskie Chodkiewiczów [dalej: AMCh], 1288; A. Lisek, Postawa Radziwittów, s. 367.

${ }^{36}$ M. S. Wiśniowiecki do J. Kości, Warszawa 22 X 1733, Biblioteka Zakładu im. Ossolińskich we Wrocławiu [dalej: BOss], 7906 (rozkaz przejścia wraz z pułkiem do dywizji białoruskiej M. F. Radziwiłła); rozkaz M. F. Radziwiłła, Słonim 3 I 1734, Biblioteka Naukowa Polskiej Akademii Umiejętności i Polskiej Akademii Nauk w Krakowie [dalej: BPAUiPAN], 698, s. 15. 
szereg uniwersałów wzywających wojsko i szlachtę do uznania jego władzy i podjęcia walki z Rosjanami ${ }^{37}$. Jego akcja była dość skuteczna, gdyż regimentarzowi „Stanisławczyków” udało się przejąć komendę nad większością chorągwi husarskich i petyhorskich, pułkiem królewskiej straży przedniej, niektórymi regimentami pieszymi i dragońskimi. Dzięki opowiedzeniu się po stronie Leszczyńskiego podwojewodziego wileńskiego Jana Antoniego Horaina (porucznika w chorągwi petyhorskiej M. F. Radziwiłła!) pod komendę Pocieja przeszły korpus artyleryjski, marszałkowska choragiew piesza i inne jednostki komputowe stacjonujące w mieście stołecznym Wielkiego Księstwa. W październiku 1733 r. siły zbrojne obozu stanisławowskiego zasiliły dwa hetmańskie regimenty, dragoński i pieszy, którymi komenderowali płk Adam Krasiński i ppłk Jerzy Puttkamer ${ }^{38}$. Po zajęciu w połowie stycznia 1734 r. Słucka Pociej podporządkował sobie drugi z hetmańskich regimentów pieszych, ale wierność służących w nim żołnierzy pozostawiała wiele do życzenia ${ }^{39}$. Dokonany na przełomie jesieni i zimy 1733/1734 r. podział armii sprawił, że Wiśniowieckiemu i Radziwiłłowi udało się utrzymać władzę nad kilkunastoma chorągwiami jazdy narodowego zaciągu oraz częścią dragonii. Nad resztą komendę przejął Pociej, który mógł dysponować do 2 500-3 000 żołnierzy, ale tylko „na papierze”. W praktyce było ich znacznie mniej, ostrożnie szacując ok. 2 000. Wiadomo, że w maju 1735 r. władzę Augusta III uznało 1221 oficerów, towarzyszy i szeregowców armii

37 Uniwersały A. Pocieja informujące o uzyskaniu regimentarstwa generalnego, Warszawa 20 IX 1733, Российский Государственный Архив Аревних Актов, Москва (РГААА), fond 12, op. 1, 75, k. 6; 24 IX 1733, LVIA, SA, 14529, k. 722-v.; uniwersały A. A. Pocieja z 16 X i 5 XI 1733, AGAD, AR, dz. II, 2487, 2490; A. Lisek, Litwini na sejmie elekcyjnym, s. 152; T. Ciesielski, Баявъъя дзеянні, s. 350.

${ }^{38}$ A. A. Pociej do J. Potockiego, 27 X 1734, BOss, 302, s. 431; J. Puttkamer do M. K. Radziwiłła, Brześć 2 XI 1733, AGAD, AR, dz. V, 12681, s. 1-2; ЦАIAУK, fond 228, op. 1, 29; doniesienia z Wilna i Warszawy X-XII 1733, Biblioteka Uniwersytetu Warszawskiego [dalej: BUW], 716; M. Matuszewicz, Diariusz życia mego, oprac. B. Królikowski, komentarz Z. Zielińska, Warszawa 1986, t. 1, s. 77; V. Rakutis, Artyleria Wielkiego Księstwa Litewskiego 1717-1764, [w:] Między Barokiem a Oświeceniem. Wojny i niepokoje czasów saskich, red. K. Stasiewicz i S. Achremczyk, Olsztyn 2004, s. 58.

39 A. Lisek, Postawa Radziwittów, s. 368-369. 
litewskiej, głównie autoramentu narodowego, stojących do tej pory po stronie Stanisława I ${ }^{40}$.

\section{Niepaństwowe sity zbrojne $w$ ostatnich latach panowania Augusta II i w trackie polskiej wojny sukcesyjnej}

W Rzeczypospolitej Obojga Narodów państwo nie miało monopolu na posiadanie wojska. Utrzymywać je mogły także: król, samorząd szlachecki, władze miejskie, instytucje kościelne, osoby prywatne. W okresach zagrożenia bezpieczeństwa publicznego czy bytu całego państwa oddziały te mogły i powinny były zasilać armię państwową. Dlatego, omawiając potencjał militarny Rzeczypospolitej w latach 1733-1735, należy uwzględnić wszystkie oddziały wojskowe i paramilitarne - monarsze, samorządowe i prywatne, a także wielki mit wojskowości doby staropolskiej - pospolite ruszenie.

\section{- Gwardia nadworna i inne oddziały królewskie}

Formacją, którą za sprawą źródeł finansowania jej utrzymania można uznać za formalnie państwową, była nadworna gwardia królewska. Ze względu na charakter wypełnianych obowiązków służbowych i podległość dowódczą była jednak przede wszystkim nadwornym, quasi-prywatnym wojskiem monarchy. W traktacie warszawskim z $1716 \mathrm{r}$. potwierdzono istnienie gwardii nadwornej, zachowując obowiązujące do tej pory w odniesieniu do niej ograniczenia prawne, a także maksymalną liczebność określoną na 1200 żołnierzy ${ }^{41}$.

${ }^{40}$ Raport gen. L. Izmaiłowa $18 \mathrm{~V}$ 1735, Biblioteka Narodowa [dalej: BN], Akc. 4634; РГААА, fond 11, 505, k. 7-v; A. F. Cichocki do J. A. Załuskiego, Warszawa 30 IV, 4 V 1735, W. H. Sierakowski do J. A. Załuskiego, Królewiec 3, 6 V 1735, F. M. Ossoliński do J. A. Załuskiego, Królewiec 26 IV, 3, 10, 24 V 1735, Korespondencja Józefa Andrzeja Zatuskiego 1724-1736, oprac. B. S. Kupść, K. Muszyńska, Wrocław i in. 1967, s. 327, 338-339, 348, 350, 358-361, 370; HHStA, Polen II, 14, k. 348, 469; А. П. Бутурлин, op. cit., s. 103-104.

41 VL, t. VI, s. 117. 
August II początkowo planował utworzenie specjalnej jednostki nie związanej z żadną armią państwową, a złożonej ze specjalnie sformowanych regimentów Garde du Corps (drabantów) i dragonów oraz kompanii artyleryjskiej. Ostatecznie borykający się z poważnymi kłopotami finansowymi monarcha odstąpił od tych zamiarów, a tzw. polską gwardię królewską do 1733 r. tworzyły odkomenderowane $\mathrm{z}$ armii saskiej regimenty i bataliony ${ }^{42}$. Przykładowo w latach $1731-1733$ były to uznawany za najlepszy w armii saskiej regiment kirasjerski gen. Krzysztofa Ernesta von Nassau, batalion grenadierów gwardii konnej, szwadron jazdy płk Jana Pawła Sybilskiego (Szybilskiego), 105 drabantów i karabinierów oraz oddział artyleryjski. Komendantem gwardii był od 1732 r. gen. mjr Christoph August hr. von Friesen. Gwardia nadworna utrzymywana była z dochodów z ekonomii królewskich, które po zmodernizowaniu systemu administrowania przynosiły ok. 650000 talarów rocznie. Niemal natychmiast po śmierci Augusta II wszystkie oddziały saskie zostały wycofane na teren elektoratu i w rezultacie gwardia nadworna przestała istnieć ${ }^{43}$.

W okresie od jesieni 1733 r. do zimy 1734 roku z oficerów i żołnierzy gwardii komputowej ściągniętych z garnizonów pomorskich oraz dragonów wydzielonych z regimentu hetmańskiego komendy płk Fabiana Wilgi, Stanisław Leszczyński utworzył w Gdańsku „nową” pieszą i konną gwardię przyboczną. O konnej nie zachowały się żadne informacje, natomiast o pieszej wiadomo, że składała się z dwu kompanii grenadierskich i ośmiu muszkieterskich. Silnie rozbudowany był korpus oficerski i podoficerski - blisko 200 ludzi. Sygnalistów było 42, grenadierów 200, a muszkieterów 1200. Łącznie w gwardii Leszczyńskiego służyło ok. 1640 żołnierzy ${ }^{44}$. Po kapitulacji Gdańska Rosjanie internowali 936 żołnierzy, w tym 462 ze „starej

42 SHD, GK, loc. 3639/2-4.

43 SHD, GK, loc. 1061/5; 3639/4-5, 3642/1; Geheimes Staatsarchiv Preussischer Kulturbesitz Berlin-Dahlem, I Hauptabteilung, Rep. 9: Polen, nr 27.60 („Haupt Relation” za rok 1732 rezydenta pruskiego K. G. Hoffmana, Warszawa 22 I 1733); Kriegsarchiv Wien, Alte Feldakten, 417, k. 25, 36-38; „Kurier Polski” 1731, nr 90, 91, 96, 97, 100.

${ }^{44}$ BCz, 2600; K. König do J. Tarły, Gdańsk 8 XI 1733, ЩАІАУК, fond 254, op. 1, 337, k. 2-3v; S. Poniatowski do J. Tarły, Gdańsk 9 XI 1733, ЦАІАУК, fond 254, op. 1, 502, k. 46; T. Dziulli do J. Tarły, Gdańsk 24 I, 27 IV 1734, ШАIAУK, fond 254, op. 2, 113, k. 7-9; S. Beym, Gdański 31 VII [1734], BCz, 2684, k. 50. 
gwardii”. Złożyli oni przysięgę wierności Augustowi III, a wielu z nich po przybyciu 12 maja 1735 roku do Warszawy zasiliło gwardię komputową ${ }^{45}$.

W ostatnich latach panowania Augusta II powstała inna jednostka, którą można zaliczyć do formacji gwardyjskich. Byli to „polscy” grandmuszkieterowie. Oddział sformowany w latach 1729-1730 miał nieformalny status kadeckiego za sprawą zapotrzebowania społecznego, składu osobowego, schematu organizacyjnego i regulaminu. Służyło w nim 80 żołnierzy, którzy od lata 1730 r. stacjonowali w Warszawie. Na sejmie konwokacyjnym postanowiono zachować oddział, który utrzymywany miał być z „dóbr ekonomicznych”. Grandmuszkieterowie zobowiązani zostali do złożenia przed marszałkiem wielkim koronnym przysięgi na wierność Rzeczypospolitej. Wielu oficerów i żołnierzy odmówiło jej złożenia, zasłaniając się koniecznością uzyskania „abszejtu” od elektora Fryderyka Augusta II, który regularnie wypłacał im pensję. Część z nich została zwolniona ze służby i wyjechała do Saksonii, inni oddalili się do domów. W rezultacie latem 1733 r. oddział, na którego utrzymanie w lipcu i sierpniu wydano ze skarbu publicznego $29080 \mathrm{zl}$, przestał istniećc ${ }^{46}$.

Inne królewskie oddziały polskiej proweniencji w chwili śmierci Augusta II znajdowały się w Saksonii. Batalion janczarski szybko został przeformowany w grenadierski, a chorągwie ułańskie zapewne zwinięto ${ }^{47}$.

45 Атака Гданска, s. 196-197; HHStA, Polen II, 14, k. 386.

46 AGAD, ASK, dz. II, 81, k. 11v i nast.; BCz, 571, s. 36, 549-551; VL, t. VI, s. 288; J. Lipski do T. Lubomirskiego, Warszawa 17 VI 1733, AGAD, APPot, 169, s. 489-493; J. Bartoszewicz, Wielcy muszkieterowie Augusta II, [w:] idem, Dzieta, t. 7, Warszawa 1880, s. 47-57; A. Haliczowa, Próba utworzenia przez Augusta II Korpusu Kadetów dla Polski, „Zeszyty Naukowe Uniwersytetu Łódzkiego”, seria I, z. 40, s. 87-91; J. Staszewski, Grandmuszkieterowie Augusta II. Nowa wersja, [w:] idem, "Jak Polskę przemienić w kraj kwitnacy..." Szkice i studia z czasów saskich, Olsztyn 1997, s. 106-116; idem, Polacy w osiemnastowiecznym Dreźnie, Wrocław i in. 1986, s. 133-136; J. Dygdała, Przygotowania stronników Stanistawa Leszczyńskiego do obrony Rzeczypospolitej $w$ bezkrólewiu 1733 roku, [w:] Między barokiem a oświeceniem, t. 4. Wojny i niepokoje czasów saskich, red. S. Achremczyk, K. Stasiewicz, Olsztyn 2004, s. 48-53.

${ }^{4}$ S. Gepner, Janczarowie polscy, „Broń i Barwa” 1935, R. 2, nr 3, s. 69-70; J. Staszewski, August II Mocny, Wrocław i in. 1998, s. 260; R. Müller, Die Armee August des Starken, Das Sächsische Heer von 1730 bis 1733, Berlin 1984, s. 36, 88-90; T. Ciesielski, Wptyw sztuki wojennej Orientu w wojskach Rzeczypospolitej, [w:] Rzeczpospolita między ok- 
Wkrótce okazało się, jak bardzo pochopna i mało rozważna była ta ostatnia decyzja, gdy po rozpoczęciu interwencji w Polsce, armia saska zaczęła odczuwać dramatyczny brak oddziałów kawalerii dorównujących mobilnością jeździe polsko-litewskiej narodowego zaciaggu. U schyłku 1733 r. pospiesznie przystąpiono do tworzenia takich oddziałów, ale fiaskiem zakończyły się próby sformowania większej liczby chorągwi jazdy z prowettyńskiej szlachty polskiej. Udało się utworzyć dwie jednostki dowodzone przez Polaków, Stobieckiego i Jabłońskiego, które cechowało niskie wyszkolenie i morale - wykazywały większą skłonność do rabunków niż udziału w operacjach bojowych ${ }^{48}$.

\section{- Milicje starościńskie i kozacy horodowi}

Oddziałami paramilitarnymi pozostającymi w służbie publicznej były milicje starościńskie. Obowiązujące prawo, ustanowione konstytucjami z lat 20. i 30. XVII w., zobowiązywało starostów, przede wszystkim z wschodnich terenów pogranicznych, do zabezpieczania zamków oraz wystawiania odpowiednio zorganizowanych i zdyscyplinowanych oddziałów paramilitarnych, oddawanych w razie potrzeby na służbę Rzeczypospolitej ${ }^{49}$. W XVIII w. starostowie, i to także niegrodowi $\mathrm{z}$ terenów południowo-wschodnich, chętnie tworzyli milicje, które były niezbędne dla zabezpieczenia królewszczyzn i dóbr dziedzicznych, głównie przed bandami rabunkowymi - hajdamakami. Ich liczebność jest nieznana i na podstawie zachowanych źródeł niemożliwa nawet do przybliżonego oszacowania. Znaczącą część milicji na kresach południowo-wschodnich Korony stanowili tzw. kozacy horodowi, wykorzystywani zarówno do pełnienia służby garnizonowej, jak i polowej, ale w zadaniach o charakterze policyjnym. W czasach saskich uważano, że starostwie grodowi powinni byli utrzymywać i oddawać w razie konieczności na „usługę” Rzeczypospolitej pod komendę hetmanów 1200 takich

cydentalizmem a orientalizmem, red. F. Wolański i R. Kołodziej, t. 1: Przestrzeń kontaktów, Toruń 2009, s. 103-104.

48 O. Schuster, F. A. Francke, Geschichte der sächsischen Armee, Leipzig 1885, th. 1, s. 209-210; T. Ciesielski, Wptyw sztuki wojennej, s. 109.

49 1620: VL, t. III, s. 182; 1624: VL, t. III, s. 222; 1627: VL, t. III, s. 260; 1632: VL, t. III, s. 350; 1638: VL, t. III, s. 446. 
kozaków $^{50}$. W rzeczywistości starostwie bardzo niechętnie wywiązywali się z tego obowiązku, a zdyscyplinowanie i lojalność ich milicji pozostawiały wiele do życzenia. Zimą 1734 r. na pewno nie wzmocniły obronności kresów południowo-wschodnich - postawa milicji starościńskiej wymusiła szybką kapitulację Białej Cerkwi, a kozacy horodowi znacznie wydatniej niż armię polską wspomagali Rosjan (zasilili jazdę nieregularną korpusu Ludwika von Hessen-Homburg) ${ }^{51}$.

Niewiele wiadomo o milicjach starościńskich na pozostałych obszarach Rzeczypospolitej. Jednym z takich oddziałów była powołana konstytucją sejmową 1726 roku i oddana pod władzę starosty krakowskiego 60-porcjowa chorągiew piechoty, która stanowiła załogę zamku królewskiego na Wawelu. Na jej utrzymanie wydzielono 100 łanów wybranieckich w województwie krakowskim. Jeżeli zawierzyć listom Franciszka Wielopolskiego, to choragiew została sformowana do zimy $1730 \mathrm{roku}^{52}$, a w trakcie bezkrólewia po śmierci Augusta II załogę Wawelu powiększono uchwałą sejmu konwokacyjnego o oddział liczący 200 porcji ${ }^{53}$. Nie są znane losy wojenne tego oddziału - na pewno nie stawił oporu Sasom, którzy zajęli bez walki Kraków i zamek królewski 24 grudnia 1733 roku ${ }^{54}$. Zapewne piechota starościńska wcześniej została wyprowadzona przez dowództwo polskie z miasta.

${ }^{50} \mathrm{BCz}, 867$, s. 62, 64; BCz, 1696, k. 105, 109; AGAD, Metryka Korona, Księgi Kanclerskie, 5b, s. 58-84; Архив Юго-Западной России, издаваемыге Временной коммиссией для разбора древних актов, ч. 3, т. 3: Акты о гайдамаках (1700-1768), Київ 1876, s. 300, 438-439, 442-443; T. Ciesielski, Kozacy w oddziatach wojskowych i milicyjnych w Rzeczypospolitej w XVIII w., [w:] Od Zborowa do NATO (1649-2009). Studia z dziejów stosunków polsko-ukrainskich od XVII do XXI wieku. Historia, red. M. Franz i K. Pietkiewicz, Toruń 2009, s. 320-321.

51 T. Ciesielski, O hajdamaczyźnie w latach 1733-1763, [w:] W kręgu Hadziacza A.D. 1658. Od historii do literatury, red. P. Borek, Kraków 2008, s. 184; T. Ciesielski, Kozacy $w$ oddziatach, s. 310-311.

${ }^{52}$ VL, t. VI, s. 212-213; F. Wielopolski do J. Tarły, Żywiec 17 III 1730, ЦАIAУ fond 181, op. 2, 2766, s. 9-10.

53 VL, t. VI, s. 288.

${ }^{54}$ T. Ciesielski, Dziatania zbrojne, s. 206, 207-208, 210. 


\section{- Wojska ordynackie}

W sytuacjach zagrożenia bezpieczeństwa kraju, zgodnie z zatwierdzonymi konstytucjami sejmowymi statutami, na usługę Rzeczypospolitej, pod komendę hetmanów lub regimentarzy generalnych, przechodziły wojska i twierdze ordynackie. W okresie polskiej wojny sukcesyjnej obóz stanisławowski mógł liczyć w zasadzie na potencjał militarny dwóch ordynacji koronnych: zamojskiej i ostrogskiej. Właściciele pierwszej utrzymywali garnizon twierdzy liczący ok. 200 żołnierzy piechoty, niewielkie oddziały artyleryjski i dragoński, reprezentacyjną choragiew husarską oraz „ad usus Rzplitej” dwie nieregularne, „polowe” choragwie dragońskie, każda po ok. 103 ludzi (formowane z osadników na prawie wojskowym, którzy posiadali „ćwierć” gruntu i powinni byli stawać zbrojnie w razie potrzeby „z koniem, rynsztunkiem i moderunkiem") ${ }^{55}$. Jesienią 1733 r. załogę Zamościa uznano za zbyt słabą i wzmocniono ją liczącym blisko tysiąc żołnierzy batalionem gwardii koronnej. Ustanowiono też wtedy „państwowego” komendanta twierdzy, którym został pułkownik artylerii koronnej Antoni Ossoliński ${ }^{56}$. Dragonów ordynackich, określanych jako kompania grenadierów konnych, skierowano do działań polowych. Na przełomie wiosny i lata $1734 \mathrm{r}$. uczestniczyli w wyprawie pomorskiej Jana Tarły, ponosząc olbrzymie straty ${ }^{57}$. Choragwie nieregularnej dragonii prawdopodobnie zabezpieczały twierdzę i w działaniach bojowych nie wzięły udziału.

Właściciele ordynacji ostrogskiej zobowiązani byli utrzymywać po 300 piechoty i jazdy. Jeżeli chodzi o pierwszą, to jej liczebność w okresie

55 AGAD, Archiwum Roskie [dalej: Aros], Militaria, pudła 16 i 20; J. Kitowicz, Opis obyczajów za panowania Augusta III, red. R. Pollak, Wrocław 1951, s. 384; M. J. Lech, Twierdza i garnizon Zamościa w latach 1752-1756, „Rocznik Lubelski” 1962, t. 5, s. 282 -287; T. Ciesielski, Milicje magnackie i ich potencjat militarny w potowie XVIII wieku. Zarys problematyki, [w:] Wobec króla i Rzeczpospolitej. Magnateria w XVI-XVIII wieku, red. E. Dubas-Urwanowicz i J. Urwanowicz, Kraków 2012, s. 786-788.

${ }^{56}$ BJ, 3605, k. 10; uniwersały M. Zamoyskiego, 6 i 8 I, 20 V 1734, AGAD, Archiwum Zamoyskich, 587, s. 191-198; A. Cieszkowski do E. Tarłowej, Zamość 7 VII 1734, BCz, 1780, s. 22 oraz Zamość 10 VII 1734, ЦАІАУK, fond 254, op. 1, 623, k. 83-83; A. Cieszkowski do J. Tarły, Zamość 23 II 1734, BCz, 1780, s. 151-154; A. Lisek, Zamość, s. 34-40.

${ }^{57}$ J. Bunt do J. Tarły, b. m. i d., ЦАІАУК, fond 254, op. 1, 166, k. 41. 
polskiej wojny sukcesyjnej nie jest znana. Wiadomo natomiast, że obsadzała zamki ordynackie, które nie stały się celem ataku ze strony wojsk rosyjskich. Wystawiana przez dzierżawców dóbr ziemskich jazda składała się z chorągwi husarskiej „złotej”, pancernej „srebrnej” i 3 tatarskich, w których łącznie mogło służyć ponad 300 żołnierzy. W ramach dywizji wołyńskiej wzięli oni udział w 1734 roku w kampanii wojennej na terenie województw południowo-wschodnich ${ }^{58}$.

W przypadku ordynacji pińczowskiej, należącej do Wielopolskich, zapis o obowiązku wystawiania 50 konnych i 100 pieszych żołnierzy na usługę Rzeczypospolitej nie przekładał się na utrzymywanie przez ordynatów milicji w takiej sile i pociągania jej do pełnienia służby publicznej. Niewykluczone, że Wielopolscy wystawili w okresie polskiej wojny sukcesyjnej jakieś oddziały wojskowe, które należy jednak zaliczyć do milicji magnackich. Ze względu na brak zapisów prawnych obligujących ordynatów do posiłkowania Rzeczypospolitej określonym kontyngentem żołnierzy za milicję magnacką uznaję także oddziały wystawione na Litwie przez właściciela rozległych dóbr nieświeskich i ołyckich"s9.

\section{- Milicje magnackie}

Poważnymi siłami zbrojnymi dysponowały osoby prywatne - przedstawiciele magnaterii i zamożnej szlachty. Jędrzej Kitowicz oceniał, że w połowie XVIII wieku w Rzeczypospolitej mogło być ok. 30000 żołnierzy nadwornych, przy czym ponad $1 / 3 \mathrm{z}$ nich znajdowała się na służbie księcia Hieronima Floriana Radziwiłła. W rzeczywistości tak wielu żołnierzy nie mieli nawet wszyscy Radziwiłłowi łącznie, na ich służbie było zapewne do 5 tys. uzbrojonych sług ${ }^{60}$. W 1733 r. trzon tej prywatnej armii Domu

58 T. Zielińska, Ordynacje w dawnej Polsce, „Przegląd Historyczny” 1977, t. LXVIII, z. 1 s. 22; T. Ciesielski, Milicje magnackie, s. 788-789.

59 T. Zielińska, Ordynacje, passim.

${ }^{60}$ AGAD, AR, dz. XXVI, 517; AGAD, ARos, Militaria, pudło 20; J. Kitowicz, op. cit., s. 387-389; S. Tomkowicz, Otyka, „Prace Komisji Historii Sztuki PAU” 1923, t. 3, s. 1-37; M. J. Lech, Milicja Radziwittów jako oręż feudatów w walce z ruchami chtopskimi na Biatorusi i Litwie, „Rocznik Białostocki” 1962, t. 3, s. 36-45; V. Rakutis, Radivilu milicija XVIII a., „Karo archyvas” 2005, nr XX, s. 101-162. 
Radziwiłłów stanowiły milicje wojewody nowogródzkiego, Mikołaja Faustyna, i ordynata nieświeskiego, Michała Kazimierza. Ten ostatni w sierpniu 1733 r. przybył do Warszawy na sejm elekcyjny w asyście chorągwi janczarów, chorągwi grenadierów, 100 rajtarów i 7 chorągwi jazdy ${ }^{61}$. Od jesieni 1733 r. wojska wojewody nowogródzkiego, ordynata nieświeskiego i ich krewnych zasilane były przez nowo zaciągnięte oddziały oraz zbrojne poczty licznej klienteli radziwiłłowskiej.

Silną milicją, rozbudowaną jeszcze w okresie bezkrólewia, dysponował Michał Serwacy Wiśniowiecki. Mogła ona liczyć nawet ok. 2 tys. ludzi, ale z braku przekazów źródłowych nie można pokusić się o bliższe szacunki ${ }^{62}$.

Wydaje się, że na znaczny wysiłek militarno-finansowy zdobyły się też dwa inne rody związane z Wielkim Księstwem, Pociejowie i Sapiehowie, których większość przedstawicieli opowiedziała się po stronie Leszczyńskiego. Każdy z tych rodów wystawił może po ok. 2 tys. żołnierzy ${ }^{63}$.

W Koronie najliczniejsze były milicje wystawione przez Potockich, przede wszystkim przez wojewodę kijowskiego i regimentarza generalnego koronnego (od września 1733 r.) Józefa Potockiego oraz wojewodę wołyńskiego i dowódcę dywizji wołyńskiej Michała Potockiego. Pierwszy z nich oddał na usługę Rzeczypospolitej cały szereg oddziałów piechoty (z zastrzeżeniem, że przede wszystkim obsadzały miasta i twierdze stanowiące własność Potockiego), dragonii i jazdy, a także swoje twierdze (choć obsadzone w dużej mierze przez żołnierzy państwowych, jak Brody czy Stanisławów). Duże zainteresowanie u współczesnych wzbudzały chorągwie tatarskie, których regimentarz miał mieć kilkanaście, a w 1735 r. zostały przejęte przez Augusta III ${ }^{64}$. W sumie wydaje się, że Potoccy wystawili 3-4 tys. żołnierzy.

Na poważny wysiłek militarno-finansowy zdobyli się też członkowie rodu Lubomirskich, ale ich żołnierze służyli po stronie obu pretendentów

${ }^{61}$ AGAD, AR, dz. VI, 80a, s. 582; J. A. Czarnecki do A. Radziwiłłowej, Biała 18 VIII 1734; AGAD, AR, dz. V, nr 2520, s. 242-243.

${ }^{62}$ Ibidem; A. Lisek, Litwini na sejmie elekcyjnym, s. 153; idem, Postawa Radziwittów, s. 366.

63 T. Ciesielski, Milicje magnackie, s. 778.

${ }^{64}$ Relacja rezydentów cesarskich z Warszawy 27 IX 1733 oraz z lat 1734-1735, HHStA, Polen III, 33, k. 352; HHStA, Polen, II, 12, k. 76-78, 132-162, 266-270; nr 14, k. 245, 257v, 329v, 348; T. Ciesielski, Wptyw sztuki wojennej, s. 109. 
do korony polsko-litewskiej. Wojewoda krakowski Teodor Lubomirski wspierał sprawę wettyńską swoją kilkusetosobową milicją, która operowała na Pogórzu Krakowskim i Spiszu ${ }^{65}$. Inni przedstawiciele rodu - Jan Lubomirski oraz starosta kazimierski Antoni Benedykt Lubomirski - opowiedzieli się po stronie Stanisława Leszczyńskiego. Pierwszy wsparł jego sprawę milicją, której trzon stanowił pułk z klucza majątkowego Białołówka (sformowany na wzór jazdy ordynackiej, utrzymywany był ze świadczeń osobistych i pieniężnych osadników wojskowych) ${ }^{66}$. Antoni Benedykt Lubomirski zasilił w lutym 1734 r. dywizję wołyńską rzekomo aż 1 tys. jazdy i dragonii nadwornej ${ }^{67}$.

Inni magnaci wsparli sprawę swojego kandydata do tronu polskiego, dostarczając od kilkudziesięciu do kilkuset żołnierzy. Przykładowo Jan Tarło jesienią 1733 r. ostentacyjnie zademonstrował swoje oddanie sprawie Leszczyńskiego i na usługę Rzeczypospolitej oddał nadworną piechotę, która miała zostać przeformowana w pododdział dragoński ${ }^{68}$. Na podstawie zachowanych źródeł nie sposób ocenić liczebności tego oddziału, podobnie jak i kontyngentów dostarczonych przez innych magnatów, co zdaje się świadczyć, że nie były one zbyt liczne, a przynajmniej nie odpowiadały deklarowanemu werbalnie na potrzeby braci szlacheckiej oddaniu sprawie czy to Augusta III, czy Stanisława I.

\section{- Oddziały miejskie}

Siły zbrojne, czy raczej policyjne praktycznie wszystkich miast królewskich składały się z niewielkich oddziałów straży miejskiej oraz powoływanego $\mathrm{w}$ razie potrzeby pospolitego ruszenia mieszczan. W XVIII w. większość miast zadowalała się kilkunastoma, w wyjątkowych przypadkach kilkudziesięcioma strażnikami (np. Warszawa 24 pachołkami dowodzonymi przez wachmistrza), którzy pilnowali bram, patrolowali ulice, kontrolowali stan

${ }^{65}$ T. Ciesielski, Dziatania zbrojne, s. 205, 218.

${ }^{66}$ A. Suszewicz do K. Polanowskiego, Radom, 7, 8 XI 1734, ЦАІАУК, fond 236, op. 2, 360; T. Ciesielski, Milicje magnackie, s. 784.

${ }^{67}$ T. Ciesielski, Agresja rosyjska, s. 112, 114.

${ }^{68}$ J. Tarło do E. Tarłowej, Warka 14 X 1733, BCz, 1779, s. 329-331. 
czystości i przestrzeganie przepisów przeciwpożarowych w mieście. Nie podlegali ewentualnym komendantom wojskowym i na dobrą sprawę pod względem wyposażenia czy wyszkolenia niewiele mieli wspólnego z wojskiem ${ }^{69}$. Pod tym względem wyróżniał się Gdańsk, który w okresie pokoju utrzymywał nawet do 1500 żołnierzy. W latach polskiej wojny sukcesyjnej garnizon miasta został powiększony do 5-6 tys. regularnych żołnierzy, a do tego dochodziło 8 tys. uzbrojonych mieszczan. Pozwoliło to miastu stawić w 1734 r. przez blisko 6 miesięcy skuteczny opór kilkunastotysięcznej armii rosyjskiej ${ }^{70}$. Jesienią 1733 r. na pewien wysiłek mobilizacyjny zdobył się Toruń, wystawiając oddział dragonów, który na początku stycznia 1734 r. został wyprowadzony z miasta przez gen. Jana Michała Kampenhauzena i włączony do operujących na Pomorzu „dywizji” polowych obozu stanisławowskiego ${ }^{71}$. W Kamieńcu Podolskim do służby wojskowej (niewątpliwie pomocniczej) zostali powołani mieszczanie z czeladzią, których rozdzielono pomiędzy 7 „dywizji”, liczących 274-341 ludzi²

\section{- Milicje instytucji religijnych i duchowieństwa świeckiego}

Wkład instytucji religijnych w potencjał militarny Rzeczypospolitej to przede wszystkim liczne ufortyfikowane klasztory i innego typu budowle stanowiące lokalne refugia. Za twierdze (fortalitium) uważano klasztory w Sokalu, a przede wszystkim na Jasnej Górze. Obsadzone były jednak przez niewielkie załogi paramilitarne, np. jasnogórska liczyła do $90 \operatorname{ludzi}^{73}$. Należy przy tym zaznaczyć, że ojcowie paulini zachowali w trakcie całe-

${ }^{69}$ J. Kitowicz, op. cit., s. 382.

${ }^{70}$ Historia Gdańska, t. 3, cz. 1, red. E. Cieślak, Gdańsk 1993, s. 321-335; E. Cieślak, W obronie tronu, s. 64-66, 68.

${ }^{71}$ Archiwum Państwowe w Toruniu, Akta Miasta Torunia, Katalog II, I-40, k. 593-597 oraz I-59, k. 23-31; Historia Torunia, t. 2, cz. 3: Między Barokiem i Oświeceniem (1660-1793), oprac. J. Dygdała, S. Salmonowicz, J. Wojtowicz, Toruń 1996, s. 209.

${ }^{72} \mathrm{APKr}$, APodh, Teki Andrzeja Potockiego (dalej: TAP), pudło VII, 1/7; М. Г. Крикун, Аюстрачія Кам'яния-Подільского 1734 р. (до питання про житловий фонд украйнського міста у XVIII cm.), „Український Археографічний Щорічник”, Нова Серія, вип.2, Київ 1993, s. 213-215; R. Król-Mazur, op. cit., s. 138, 599-610.

73 APKr, AMCh, 1283; S. Szymański, Fortalitium jasnogórskie w Częstochowie, „Kwartalnik Architektury i Urbanistyki” 1963, t. 8, z. 2, s. 144-155; W. Kędera, Jasna 
go konfliktu neutralność. Inaczej postąpili najważniejsi duchowni świeccy, dysponujący oddziałami nadwornymi i artylerią - arcybiskup gnieźnieński Teodor Potocki i biskup krakowski Jan Aleksander Lipski - którzy otwarcie zadeklarowali się po stronie jednego z pretendentów do tronu.

\section{Pospolite ruszenie i wyprawy wojewódzkie}

W razie szczególne zagrożenia państwa armię regularną miało wzmocnić pospolite ruszenie. Faktycznie jednak zanikło ono w połowie XVII wieku po kompromitujących dla szlachty i całej wojskowości polskiej wyprawach z lat 1648-1655. Przetrwał mit, zgodnie z którym w razie szczególnego zagrożenia kraju na wezwanie władcy stanąć miało pod bronią sto i więcej tysięcy szlachty. W 1726 r. przypomniano o nim, „aby cały świat widział”, konstytucjami sejmowymi „Pospolite ruszenie Koronne” i „Pospolite ruszenie W. X. Lit.”. Konsekwentnie w 1733 r. sejm konwokacyjny podjął uchwałę upoważniającą prymasa do zwołania pospolitego ruszenia w razie wmieszania się w sprawy polskie któregoś z sąsiednich państw ${ }^{74}$. Gdy jednak to nastąpiło i Stanisław Leszczyński wydał wici na pospolite ruszenie, szlachta nie wykazywała ochoty do masowego i osobistego stanięcia w obronie niedawno wybranego władcy. Przystąpiła w zamian do uchwalania i powolnego organizowania oddziałów wyprawnych. O ich wielkości decydowały sejmiki. Większość koronnych uchwaliło wystawienie jazdy typu pancernego. Tylko nieliczne sejmiki powołały formacje piesze, jak województwa podolskie, poznańskie i kaliskie oraz prowincja pruska. Zobowiązania województw i ziem koronnych przedstawiały się następująco ${ }^{75}$ :

Góra wobec przemian politycznych w Rzeczypospolitej w latach 1661-1813, „Studia Clarmontana” 1993, t. 13, s. 143-145.

74 VL, t. VI, s. 206, 289.

75 BOss, 300, k. 36v-39; BOss 2634, k. 40-43; ЦАІАУК, fond 49, op. 1, 2624, k. 74-82; ЦАІАУК, fond 254, op. 1, 69, k. 1-4; Akta grodzkie i ziemskie z czasów Rzeczypospolitej Polskiej z Archiwum tak zwanego Bernardyńskiego we Lwowie, t. 23: Lauda sejmikowe wiszeńskie, lwowskie, przemyskie, sanockie 1731-1772, wyd. A. Prochaska, Lwów 1928, s. 56-60 oraz t. 25: Lauda sejmików halickich 1696-1772, wyd. W. Hejnosz, Lwów 1935, s. 378; K. Przyboś, Sejmik województwa krakowskiego w czasach saskich (1697-1763), Kraków 1981, s. 134-135; A. Lisek, Rola Kamieńca Podolskiego dla obozu stanistawowskie- 
- Województwo wołyńskie - 15 chorągwi o łącznej liczebności 1200 koni.

- Województwo lubelskie - 4 chorąwie jazdy w sile 400 ludzi.

- Województwo ruskie - 780 kawalerzystów („pachołków” z dobrymi końmi, uzbrojonych w karabiny, pistolety, szable i dzidy) i 60 dragonów z ziemi przemyskiej, lwowskiej, sanockiej oraz znajdujących się na ich terenie królewszczyzn i ekonomii, a także 4 chorągwie w sile 300 koni z ziemi halickiej.

- Ziemia chełmska - 2 chorągwie stukonne, 300 pachołków.

- Województwo podolskie - 2 chorągwie pancerne po 100 koni każda oraz 300 „pachołków”.

- Województwo krakowskie - w grudniu 1733 r. zatrzymało w służbie istniejącą już stukonną chorągiew oraz postanowiło wystawić 7 nowych choragwi jazdy w sile 690 koni (rekrutowane w systemie dymowym, żołnierze uzbrojeni we flintę i pistolety, odziani w barwę granatowa) oraz 94 pachołków z powiatów sądeckiego, bieckiego i księstwa siewierskiego. Uchwały tej nie udało się w pełni zrealizować i 20 września 1734 roku szlachta zgromadzona na pospolitym ruszeniu postanowiła przejąć na swoje utrzymanie już istniejące i pozostające pod komendą marszałka konfederackiego Jerzego Ożarowskiego oddziały w sile 660 dragonów i jazdy narodowego zaciągu ${ }^{76}$.

- Województwa poznańskie i kaliskie - w 1734 r. postanowiły utworzyć obok 6 chorągwi jazdy także po regimencie pieszym i dragońskim. Oba miały charakter wyprawny: pierwszy z dóbr szlacheckich po 1 pieszym z 10 dymów, drugi z dóbr duchowieństwa - po 1 dragonie z 20 łanów. Kilka miesięcy po utworzeniu obu regimentów, 1 października 1734 roku, w dragońskim było 30, a w pieszym

go w województwie podolskim w latach 1733-1736, „Rocznik Przemyski” 2005, t. XLI, z. 4, Historia, s. 10; idem, Obóz stanistawowski w województwie ruskim w okresie bezkrólewia w 1733 r. i w pierwszych miesiacach wojny o tron polski, „Rocznik Przemyski”2000, t. XXXVI, z. 4, Historia, s. 13-14; idem, Stanowisko szlachty województwa wotyńskiego wobec wydarzeń $w$ Rzeczypospolitej $w$ latach 1733-1736, „Rocznik Przemyski” 2009, t. XLV, z. 4, Historia, s. 12.

${ }^{76}$ T. Ciesielski, Dziatania zbrojne, s. 218. 
40 żołnierzy „wypróbowanych”, ale słabo wyposażonych i schorowanych ${ }^{77}$.

Na czele wypraw wojewódzkich i ziemskich stali wybrani pułkownicy, ale zazwyczaj dowództwo operacyjne nad nimi przejmowali marszałkowie lokalnych konfederacji. Część z nich potrafiła przy tym zgromadzić tylko niewielkie „partie” wojska, które po kilku tygodniach działań „w polu” redukowały się do 5-6 chorągwi, w których służyło po zaledwie 30-40 towarzyszy, jak latem 1734 roku w zgrupowaniach dowodzonych przez marszałka konfederacji poznańskiej i kaliskiej Jana Antoniego Polendzkiego, czy marszałka konfederacji sieradzkiej Jana Antoniego Walewskiego ${ }^{78}$. Nieco większym oddziałem dysponował w 1734 r. marszałek województwa krakowskiego, oboźny koronny Jerzy Ożarowski - zapewne z około 600 żołnierzami $^{79}$. Do najsilniejszych należały zgrupowania bojowe dowodzone przez marszałka województwa wołyńskiego, wojewodę wołyńskiego Michała Potockiego oraz marszałka pruskiego, kasztelanica rypińskiego Sebastiana Mełdzyńskiego. Obie przy tym wyprawy zachowały dużą samodzielność przez cały czas trwania wojny ${ }^{80}$.

Zimą 1734 r. liczebność wypraw wojewódzkich i ziemskich wystawionych w Koronie przez stronników Leszczyńskiego szacowano na ok. 10400 żołnierzy. W następnych miesiącach powiększyły się może do 18000 ludzi, a to za sprawą dołączenia nowych województw oraz zwiększenia wysiłku militarnych tych, które już wystawiły oddziały wyprawne, np. Wołynianie zamiast 1200 utrzymywali 2000 żołnierzy. Należy przy tym podkreślić, że niektóre województwa bardzo długo nie kwapiły się z wystawieniem swoich

77 P. Sokolnicki do J. Tarły, Kalisz 26 VI 1734, ЦАІАУК, fond 254, op. 1, 581, k. 5-6; J. A. Polendzki do J. Tarły, 27 VI i 1 X 1734, ШАІАУK, fond 254, op. 1, 483, k. 21-22, 49-50.

78 J. A. Polendzki do J. Tarły z V-IX 1734, ЦАІАУК, fond 254, op. 1, 483, k. 7-44; J. A. Walewski do J. Tarły, 13 VIII-9 X 1734, ЦАІАУК, fond 254, op. 1, 204, k. 1-21.

79 T. Ciesielski, Dziatania zbrojne, s. 210, 217-218.

80 T. Ciesielski, Agresja rosyjska..., s. 117-124; idem, Prusy Wschodnie w trakcie polskiej wojny sukcesyjnej i wojny siedmioletniej, [w:] Wielkie wojny w Prusach, red. N. Kasparek, W. Gierszewski, Dąbrówno 2010, s. 105-107; S. Achremczyk, Obóz stanistawowski w Prusach Królewskich w latach 1733-1736, „Rocznik Gdański” 1986, t. 46, z. 1, passim; idem, Warmia wobec wydarzeń, passim. 
wypraw - przykładowo jeszcze 6 czerwca 1734 r. regimentarz generalny Józef Potocki wzywał do tego szlachtę łęczycką za pośrednictwem jej marszałka, chorążego gostyńskiego Jana Malińskiego ${ }^{81}$, a ziemia łomżyńska dopiero 19 lipca 1734 r. uchwaliła wystawienie 100-konnej choragwi wyprawnej oraz zobowiązała do służby publicznej strzelców z puszcz łomżyńskiej i ostrołęckiej ${ }^{82}$.

Po zawiązaniu w październiku 1734 r. konfederacji generalnej, jej marszałek, starosta jasielski Adam Tarło, stał się zwierzchnikiem wypraw wojewódzkich, które miały zostać znacząco rozbudowane. Pozostało to jednak tylko w sferze niezrealizowanych planów. W marcu 1735 r. Rada Wojenna ustanowiona przy marszałku generalnym prostanisławowskiej konfederacji dzikowskiej, sporządziła wykaz chorągwi wojewódzkich, których liczebność oszacowano na 10665 ludzi. Poszczególne województwa miały utrzymywać następującą liczbę żołnierzy i oddziałów ${ }^{83}$ :

- Województwo wołyńskie - 2060; w tym 11 chorągwi jazdy 900, dragonii 160, „Lipków” (jazda tatarska?) 1000.

- Województwo krakowskie - 1490; w tym 7 chorągwi pancernych 770, 5 chorągwi lekkich 400, dragonii 200, pachołków 120.

- Mazowsze - 1212 jazdy.

- Województwo sandomierskie - 1150; w tym 3 chorągwie lekkie 300, dragonii 200, pachołków 650.

- Województwa poznańskie i kaliskie - 700; w tym 6 chorągwi jazdy 550, piechoty 100, pachołków 50 .

- Województwo ruskie - 480; w tym 4 chorągwie jazdy 420, dragonii 60.

- Województwo podlaskie - 460 jazdy (ale bez ziemi mielnickiej, która nie przysłała 100 ludzi).

- Prusy Królewskie - 453; w tym 2 chorągwie jazdy 160, dragonia 163 , piechota 130 .

- Województwo podolskie - 420 jazdy w 6 chorągwiach.

- Województwo rawskie - 300 jazdy.

81 BOss, 348, k. 161-162.

${ }^{82}$ BPAUiPAN, 8332, k. 268-271v.

${ }^{83} \mathrm{BCz}, 576$, s. 320-324. 
- Województwo lubelskie - 280 jazdy w 4 chorągwiach.

- Województwo sieradzkie - 270 jazdy w 5 chorągwiach.

- Województwo bełskie - 200 w 4 chorągwiach.

- Województwo łęczyckie - 200 jazdy w 2 chorągwiach.

- Ziemia chełmska - 200 jazdy.

- Ziemia wieluńska - 40 pachołków.

Do tego dochodziło 640 żołnierzy jazdy i 70 dragonów marszałka generalnego konfederacji, starosty jasielskiego Adama Tarły.

Wojciech Stanek w swojej pracy poświęconej konfederacjom generalnym w osiemnastowiecznej Polsce ocenił, że wyprawy wystawione przez województwa koronne nie stanowiły wystarczającej siły zbrojnej „zarówno co do liczebności, jak i struktury dla odniesienia jakichkolwiek sukcesów militarnych nad wojskiem saskim i rosyjskim”, zwłaszcza w obliczu przejścia na stronę wettyńską dużej części oddziałów komputowych ${ }^{84}$.

Szlachta Wielkiego Księstwa, skonfederowana w obronie tronu Stanisława I, także preferowała oddziały wyprawne. Żmudzini rzekomo już jesienią 1733 r. wystawili 20 chorągwi jazdy zebranych przez Antoniego Zaborowskiego ${ }^{85}$. Większość województw i powiatów decyzje o wystawieniu oddziałów wyprawnych podjęło dopiero na przełomie zimy i wiosny 1734 r. na zjazdach, na których zawiązano konfederacje. $Z$ reguły zadeklarowały wystawienie 1-4 choragwi jazdy; na przykład powiat lidzki 3 chorągwie, powiat mozyrski - stukonną choragiew i oddział piechoty utworzony z rekrutów dostarczanych po jednym z każdych 10 dymów, powiat oszmiański - prawdopodobnie także jedną choragiew jazdy i piechotę wyprawną, województwo mińskie - stukonną chorągiew petyhorską ${ }^{86}$.

${ }^{84}$ W. Stanek, Konfederacje generalne w Koronie w XVIII wieku, Toruń 1991, s. 116.

85 A. Lisek, Obóz stanistawowski na Litwie, s. 131.

${ }^{86}$ Нацыянальны Гістарычны Архіў Беларусі, Мінск (НГАБМ), fond 1727, op. 1, 10, k. 152; fond 1728, op. 1, 8, k. 670; fond 1871, op. 1, 1, k. 380-381; fond 1730, op. 1, 2, k. 359; Biblioteka Narodowa w Warszawie, 9046; BPAUiPAN, 1856, s. 254-257; AGAD, Zbiór Komierowskich, 62/82; Lietuvos Mokslų Akademijos Biblioteka, Vilnius, fondas 17, 52, k. 47-48 oraz fondas 273, 1661; M. Matuszewicz, op. cit., t. 1, s. 79-80; A. Macuk, Konfederacje powiatów Wielkiego Księstwa Litewskiego w obronie Stanistawa Leszczyńskiego w latach 1733-1736, [w:] Król a prawo stanów do oporu, red. M. Markiewicz, E. Opaliński i R. Skowron, Kraków 2010, s. 321-329. 
Do znacznego wysiłku finansowo-organizacyjnego zobowiązały się szlachta z powiatu trockiego oraz województwa nowogródzkiego. Pierwsza na zjeździe w Olicie 20 marca 1734 r. uchwaliła wystawienie 3 choragwi autoramentu polskiego i 200 piechoty, a druga 5 marca 1734 roku 4 choragwi jazdy i oddziału jednolicie umundurowanej piechoty. Szlachta z województwa brzeskiego litewskiego postanowiła na zjeździe 5 maja 1734 r. wystawić 4 chorągwie jazdy i 500 piechoty. Koszty utrzymania tych oddziałów ponosiła oczywiście także i szlachta pińska, która 24 maja, w zamian za wystawienie jednego żołnierza z każdych 20 dymów, uchwaliła podatek 10-złotowy, a ponadto zobowiązała się do stawienia na pospolite ruszenie, jeżeli tylko zostanie zwołane ${ }^{87}$. Na podstawie zachowanych uchwał sejmikowych nie sposób precyzyjne określić wielkości zadeklarowanych przez stronników Stanisława I wypraw w skali całego Wielkiego Księstwa. Wydaje się, że ich łączna liczebność nie przekraczała 5 tys. ludzi. Nie stanowiły przy tym wielkiego wzmocnienia dla walczącej armii za sprawą słabego wyszkolenia i jeszcze gorszego wyposażenia. Marcin Matuszewicz podaje, że piechota wyprawna powiatu oszmiańskiego nie miała doświadczonych oficerów, a uzbrojona była w piki zamiast w broń palną. Co więcej, do obozu przyprowadziła „armaty dębowe” 88 .

Nie do końca wiadomo, jak przebiegał proces wystawiania przez obóz prostanisławowski oddziałów wyprawnych wobec przewagi osiągniętej na terytorium Wielkiego Księstwa przez połączone siły rosyjskie oraz zwolenników Wettyna. Trzon tych ostatnich stanowiły oddziały komputowe oraz milicje radziwiłłowskie i Michała Serwacego Wiśniowieckiego. Wzmocnione zostały drogą wolnych zaciągów szlacheckich, a także przez wyprawy z województw i ziem. Wiadomo, że „stojąca” przy Auguście III

${ }^{87}$ НГАБМ, fond 1705, op. 1, 51, k. 110-113; AGAD, AR, dz. II, 2502; APKr, AMCh, 1018 (województwo brzeskie litewskie); Аьвівска Наукова Бібліотека НАН України ім. В. Стефаника (dalej: АНБ), fond 5, 1422, k. 243v-244 (powiat piński); НГАБМ, fond 1730, оp. 1, 2, k. 359; РНБ, fond 971, op. 2, АА, 126, k. 194-195v (województwo nowogródzkie); A. Zakrzewski, Sejmiki Wielkiego Księstwa Litewskiego XVI-XVIII w. Ustrój i funkcjonowanie sejmiku trockiego, Warszawa 2000, s. 189.

${ }^{88}$ M. Matuszewicz, op. cit., t. 1, s. 79-80. 
szlachta żmudzka zadeklarowała na zjeździe 20 kwietnia 1734 r. wystawienie 2 petyhorskich chorągwi stukonnych ${ }^{89}$.

\section{Artyleria}

\section{- Artyleria państwowa}

Artyleria koronna stanowiła odrębną formację, którą dowodził generał artylerii koronnej, a w jej skład wchodził liczący do 200 osób personel rozdzielony między sztab, 8 arsenałów i frejkompanię dragońską, a także sprzęt artyleryjski ${ }^{90}$. W trakcie polskiej wojny sukcesyjnej doszło do sytuacji, w której dowódca artylerii Jan Klemens Branicki opowiedział się po stronie Wettyna, a niemal wszyscy jego podkomendni służyli po stronie stanisławowskiej. Co więcej, 18 marca 1734 r. Branicki został pod Olkuszem wzięty do niewoli przez Adama Tarłę i następnie osadzony w Kamieńcu Podolskim. Wraz z generałem artylerii „Stanisławczykom” dostała się frejkompania artylerii, która liczyła do 50 dragonów (taki stan wykazywała latem 1732 r.). W pierwszych miesiącach wojny pełnili oni funkcję straży przybocznej Branickiego, ale pod Olkuszem nie wykazali większej ochoty bronienia swojego pryncypała i już na samym początku potyczki złożyli bron $^{91}$. Właściwy korpus artylerii liczył 125-130 oficerów, podoficerów, artylerzystów, felczerów, urzędników cywilnych i woźniców. Do lata 1734 r. zdecydowana większość z nich - 91 żołnierzy - znalazła się w Kamieńcu Podolskim ${ }^{92}$. Wynikało to z faktu ewakuowania niemal wszystkich załóg arsenałów i przeniesienia ich na Podole. W styczniu 1734 r. utracona została komenda artyleryjska z Białej Cerkwi, internowana przez Rosjan po kapitulacji twierdzy ${ }^{93}$. Personel był najmocniejszą stroną artylerii koronnej (jak

89 LVIA, SA, 14529, k. 490-491.

90 T. Ciesielski, Armia koronna, s. 357-374.

${ }^{1}$ APKr, Zbiór Rusieckich, 151, t. 1, s. 1117, 1123-1125, 1211; AGAD, Archiwum Roskie, Militaria, pudło 17; J. Benda, Kampamenty, s. 332; J. Wimmer, Historia piechoty, s. 312; T. Ciesielski, Dziatania zbrojne, s. 214-215.

${ }^{92}$ APKr, APodh, I, 93; II, 360, 363; TAP, pudło VI, 3/2.

93 T. Ciesielski, Agresja rosyjska, s. 108. 
też i litewskiej), gdyż cechowało go dobre wykształcenie i fachowe przygotowanie, zdyscyplinowanie oraz morale. Znacznie gorzej prezentował się sprzęt artyleryjski, gdyż w okresie Wielkiej Wojny Północnej artyleria koronna poniosła w tym zakresie olbrzymie straty. W niewielkim tylko stopniu udało się odbudować stan parku artyleryjskiego w latach 1711-1733, kiedy to w ludwisarni kamienieckiej i kuźnicach samsonowskich biskupów krakowskich odlano kilkadziesiąt dział spiżowych i żelaznych. Ponadto artyleria koronna pozyskała kilkanaście armat podarowanych przez Teodora Potockiego i innych magnatów. W sumie w połowie 1733 r. artyleria państwowa w Koronie dysponowała: ok. 230 armatami spiżowymi i żelaznymi o 15 wagomiarach kul od 48- do 0,75-funtowego; 15 szrotownicami spiżowymi i żelaznymi; 53 moździerzami spiżowymi i żelaznymi o 19 wagomiarach od 125- do „ręcznych”; 6 śmigownicami; 372 hakownicami i muszkietami murowymi. Ponadto we wrześniu 1733 r. Polacy zarekwirowali lekkie armaty zdobyte w pałacu saskim w Warszawie. Zasiliły one sprzęt polowy, którego nie było zbyt wiele - ok. 50 armat regimentowych, haubic i lekkich moździerzy, a i tak tylko nieliczne użyto w działaniach polowych w latach 1733-1735. Resztę dział wykorzystywano jako forteczne. Mankamentem sprzętu artyleryjskiego był jego zły stan techniczny ${ }^{94}$.

Litewski korpus artyleryjski nie ustępował zbytnio pod względem liczebności koronnemu, gdyż w planie komputu wydzielono na jego utrzymanie 150 porcji rozdzielonych między sztab, personel artyleryjski (kanonierski) i frejkompanię grenadierską. Kadrę oficerską częściowo

${ }^{4}$ BOss, 286, s. 184-194; APKr, Archiwum Dzikowskie Tarnowskich, 384, s. 186-192; AGAD, Zbiór Popielów, 341, k. 19; BJ, 5349, s. 135. K. Górski, Historya artyleryi polskiej, Warszawa 1902, s. 312-313; J. Wimmer, Wojsko Rzeczypospolitej, s. 478-493; M. Wagner, Zmiany w uzbrojeniu wojsk polskich na poczatku XVIII wieku, [w:] Technika a wojna $X-X X$ w., red. P. Matusak i J. Piłatowicz, Siedlce 2000, s. 147; T. M. Nowak, Fortyfikacje i artyleria Kamieńca Podolskiego $w$ XVIII w., „Studia i Materiały do Historii Wojskowości” 1973, t. XIX, z. 1, s. 178-183; I. В. Аанілов, Артилерійське забезпечення Кам'янещь-Подільськой фортечі XV II-XV III cm., „Наукові праці Кам’янець-Подільского Аержавного Педагогічного Університету", Історичні наукі, 1998, т. 2 (4), s. 219; T. Ciesielski, Archibald Andrzej Glower. Podputkownik artylerii koronnej - XVIII-wieczny fortyfikator Kamieńca Podolskiego, [w:] Primum Vivere Deinde Philosophari. O ludziach czynu $w$ dziejach Europy Środkowej $i$ Wschodniej, red. M. Białokur i A. Szczepaniak, Opole-Toruń 2009, s. 128-142; idem, Armia koronna, s. 370-376, 386-387. 
utrzymywano z właściwego budżetu artylerii i dlatego efektywność wykorzystania środków osobowych była bardzo wysoka. Stosunkowo niskie były przy tym koszty utrzymania żołnierzy, gdyż wszyscy stacjonowali w Wilnie lub okolicznych folwarkach i jurydykach stanowiących tzw. „dobra artylleryczne”. Etatowo cały korpus artylerii liczył od 116 do 121 ludzi, w tym 4-9 w sztabie, 36-41 kanonierów oraz 70-76 grenadierów ${ }^{95}$. Tak rozbudowany korpus osobowy odbijał się niekorzystnie na technicznym wyposażeniu litewskiej artylerii państwowej. W 1717 r. dysponował ona zaledwie 10 działami. Cały sprzęt i zapasy zdeponowane były w jedynym arsenale Wielkiego Księstwa w Wilnie ${ }^{96}$. Wiadomo jedynie, że jesienią 1733 r. obóz stanisławowski wraz z Janem Antonim Horainem pozyskał 12 dział i 40 artylerzystów. Część sprzętu utracono w starciu pod Sielcami 19 sierpnia 1734 roku, a pozostałe pod Królowym Krzesłem w maju 1735 roku ${ }^{97}$.

\section{- Artyleria miejska, ordynacka, instytucji religijnych i prywatna}

Cennym uzupełnieniem dla artylerii państwowej były zasoby arsenałów miejskich, ordynackich, instytucji religijnych, a przede wszystkim prywatnych. Jeżeli chodzi o pierwsze, to największą ilością sprzętu spośród miast dysponowały Gdańsk i Elbląg. Pierwsze posiadało na początku XVIII w. ponad 300 dział $^{98}$, a w 1734 r. chyba nawet więcej, skoro w samej tylko twierdzy Wisłoujście w chwili jej kapitulacji 24 czerwca 1734 r. znajdowało się 111 armat i 5 moździerzy ${ }^{99}$. Inwentarze artylerii elbląskiej sporządzane

${ }^{5}$ V. Rakutis, Artyleria, s. 55-58; M. J. Lech, Autorament cudzoziemski, s. 108-109. Najbliższe 1733-1735 znane mi dane źródłowe dot. stanu liczebnego korpusu artylerii pochodzą z jesieni 1736 i 1737 r.: AGAD, AR, dz. VII, 89 i 90.

${ }^{96} \mathrm{~J}$. Wimmer, Wojsko Rzeczypospolitej, s. 483.

${ }^{77}$ РГААА, fond 11, 429, k. 290-295; РГААА, fond 177, 1734, 16, k. 2; BOss, 302, s. 650-652; J. Lipski do T. Lubomirskiego, Warszawa 20 IX 1734, AGAD, APPot, 169, s. 398-399; AGAD, AR, dz. VI, 81a, s. 652-656; M. Matuszewicz, op. cit., t. 1, s. 82; LVIA, SA, 18369, k. 406; V. Rakutis, Artyleria, s. 58.

${ }^{98} \mathrm{~J}$. Wimmer, Wojsko polskie $w$ drugiej potowie XVII w., Warszawa 1965, s. 324; J. Stankiewicz, Nadmorska twierdza w Wistoujściu, „Kwartalnik Architektury i Urbanistyki” 1956, t. 1, z. 2, s. 137-139.

99 Атака Гданска, s. 146-149; А. П. Бутурлин, ор. cit., s. 76-79; Ch. Mannstein, Записки о России, [w:] Перевротьи и войньи, Москва 1997, s. 58; Historia Gdańska, t. 3, сz. 1, 
w latach 1716-1733 wyliczają 3 ciężkie moździerze 125- i 100-funtowe, 3 lekkie 6,5-3,5-funtowe, 112 dział 18 -1-funtowych oraz 17 falkonetów 26 - 8-funtowych ${ }^{100}$. Trzecie z miast pomorskich, Toruń, dysponował tylko 16 małych wagomiarów, ale za to nowoczesnymi działkami żelaznych, nabytymi w latach 20 . XVIII wieku ${ }^{101}$. Niewątpliwie był to bardziej wartościowy sprzęt niż artyleria Lwowa, na którą składały się co prawda 32 armaty oraz 78 hakownic, śmigownic i organków, ale przestarzałych i w większości niezdatnych do użytku ${ }^{102}$. Na stanie ordynacji zamojskiej było do 111 dział i tyle samo przestarzałych hakownic, czego nie uznawano za wystarczające zabezpieczenie artyleryjskie Zamościa, skoro w 1733 r. do twierdzy wysłano 24 armaty zarekwirowane w Rzeszowie ${ }^{103}$. Jeszcze gorzej wyglądała sytuacja w ordynacji ostrogskiej, gdyż w głównej twierdzy Dubno było co najwyżej 20 dział i 28 hakownic, a do tego dochodziła niewielka ilość przestarzałego sprzętu artyleryjskiego w Ostrogu ${ }^{104}$. Spośród instytucji religijnych zdecydowanie wyróżniał się klasztor oo. paulinów na Jasnej Górze ochraniany przez około $100 \mathrm{dzia}^{105}$.

W posiadaniu magnatów i średnio zamożnych szlachciców znajdowało się od kilku do nawet kilkuset armat i moździerzy. Przykładowo wła-

s. 530-532.

100 Archiwum Państwowe w Gdańsku, Akta Miasta Elbląga, Rada Miasta, Komisariat Wojenny, 369, 1/3009, k. 23, 45-51, 53.

101 Archiwum Państwowe w Toruniu, Akta Miasta Torunia, Katalog II, I-40, k. 659; Historia Torunia, t. II, cz. 3, s. 208-209.

102 Inwentarz z 2 V 1724, Pamiętniki dziejów polskich z aktów urzędowych lwowskich i z rękopismów zebrat X.Sadok Barącz, Lwów 1855, s. 167-169; AGAD, AR, dz. V, 1334, s. 330-331; AGAD, Metryka Koronna, 267, s. 286-288, 296.

103 A. Cieszkowskiego do J. Tarły, Zamość 25 II 1734, BCz, 1780, k. 153; J. Nieć, Rzeszowskie za Sasów, Rzeszów 1938, s. 82; A. Lisek, Zamość, s. 36.

${ }_{104} \mathrm{Z}$ braku materiału źródłowego z lat 30. oparłem się na inwentarzach z lat 50 . i początku 60., z których można wysnuć wniosek, że w drugiej ćwierci XVIII w. nie doszło do znaczącego ubytku sprzętowego: AGAD, Zbiór Anny Branickiej, 1807a, k. 66-69; AGAD, ARos, Militaria, pudło 19; A. Dortmann do J. K. Branickiego, Dubno 4 IX 1754, 12 VIII 1756, AGAD, ARos, Korespondencja, pudło V, 46, s. 14-15, 62; T. Opas, Inwentarz twierdzy dubieńskiej z 1759 r., „Kwartalnik Historii Kultury Materialnej” 1985, R. 33, z. 3, s. 244-247.

105 J. Kitowicz, op. cit., s. 386; S. Szymański, Fortalitium jasnogórskie w Częstochowie, „Kwartalnik Architektury i Urbanistyki” 1963, t. 8, z. 2, s. 144-155. 
snością kilku linii Lubomirskich była następująca liczba dział: w Rzeszowie ok. 40, w Łańcucie minimum 24, w Kolbuszowej 30, a nie wiadomo, jaki był stan parku artyleryjskiego zgromadzonego w Połonnem ${ }^{106}$. Czartoryscy posiadali 78 dział (21 niesprawnych), 108 hakownic oraz blisko tysiąc sztuk różnej broni palnej zdeponowanych w samych tylko Brzeżanach (Korona), a także 5 dział, 3 śmigownice, 6 moździerzy i 78 hakownic na zamku w Szkłowie (Litwa) ${ }^{107}$. Na ziemiach koronnych najsilniejszą artylerią dysponował niewątpliwie Józef Potocki - w samym Stanisławowie grubo ponad 100 dział różnego typu, a do tego dochodziło zabezpieczenie artyleryjskie innych twierdz będących we władaniu tego magnata ${ }^{108}$. W Wielkim Księstwie Litewskim najlepiej w artylerię wyposażone były twierdze radziwiłłowskie w Słucku i Nieświeżu - łącznie ponad 80 armat i moździerzy ${ }^{109}$. Ordynat nieświeski (w okresie polskiej wojny sukcesyjnej Michał Kazimierz Radziwiłł) posiadał też niewątpliwe działa w innych ważnych ośrodkach swoich ogromnych włości, a do tego dochodził sprzęt artyleryjski będący w posiadaniu innych linii rodu radziwiłłowskiego - może i blisko pół tysiąca armat, moździerzy, hakownic itd. Zasobnymi arsenałami dysponował również Wiśniowiecki - przynajmniej kilkadziesiąt różnego typu dział i to w miarę nowoczesnych (część z nich, może 18, utracił pod Warszawą we wrześniu 1733 r.).

Część prywatnego sprzętu artyleryjskiego aktywnie wykorzystano w działaniach bojowych w latach 1733-1735 i to nie tylko w obronie włości danego magnata czy szlachcica. Wiadomo, że w 1734 r. osłonę artyle-

106 A. Cieszkowski do J. Tarły, Zamość 23 II 1734, BCz, 1780, s. 153 i J. Nieć, op. cit., s. 82; W. Szczygielski, Lubomirski Maciej, PSB, t. 28, Wrocław i in. 1973, s. 35.

107 АНБ, fond 5, 2104; APKr, APodh, II, 360; A. P. Hryckiewicz, Warowne miasta magnackie na Biatorusi i Litwie, „Przegląd Historyczny” 1970, t. LXI, z. 3, s. 440.

108 Według inwentarza sporządzonego w X 1754 r. przez ppor. Kazimierza Hilchena w arsenale i na obwałowaniach stanisławowskich znajdowały się 123 działa i haubice spiżowe oraz żelazne, 3 moździerze, śmigownica i 2 hakownice; AGAD, Zbiór Czołowskiego, 17, s. 42-56. W literaturze wspomina się nawet o ponad 200 działach: A. Szarłowski, Stanistawów i powiat stanistawowski pod względem historycznym i geograficzno-statystycznym, Stanisławów 1887, s. 71, 129-130; S. R. Krawcow, Stanistawów w XVII-XVIII w. Uktad przestrzenny i jego symbolika, „Kwartalnik Architektury i Urbanistyki” 1993, t. 38, z. 1, s. 3-19.

109 A.P. Hryckiewicz, op. cit., s. 433, 437. 
ryjską Kamieńca Podolskiego wzmocniły armaty stanowiące własność wojewody wołyńskiego Michała Potockiego, chorążego koronnego Wacława Rzewuskiego oraz starościny Małachowskiej ${ }^{10}$. Prywatne lekkie działa wykorzystywane były przez stronników Wettyna i Leszczyńskiego w działaniach polowych, często w przypadku tych ostatnich stając się po przegranych potyczkach łupem Rosjan. Ci ostatni wiosną 1734 r. splądrowali państwowe i miejskie arsenały na Pomorzu, zabierając z nich cały sprzęt, który nadawał się do wykorzystania w walkach o Gdańsk ${ }^{111}$.

$\mathrm{Na}$ podstawie zachowanych źródeł nie sposób oszacować stanu ilościowego i jakościowego sprzętu artyleryjskiego pozostającego w posiadaniu miast i osób prywatnych. Na pewno było go kilkakrotnie więcej niż państwowego, a pewien odsetek stanowiły armaty i moździerze stosunkowo nowej produkcji, choć w większości niewielkich wagomiarów. Podstawowym problemem artylerii miejskiej i prywatnej był brak wyszkolonego personelu. Istnienie wyspecjalizowanych pododdziałów artyleryjskich można stwierdzić jedynie w przypadku milicji gdańskiej i toruńskiej, ordynackich oraz radziwiłłowskich.

\section{Podsumowanie}

W latach 1733-1735 Rzeczypospolita, podzielona na dwa obozy i skonfederowana przy obu pretendentach do tronu, zdobyła się na znaczny wysiłek militarno-finansowy. Pod bronią znalazło się w wojskach państwowych, królewskich, samorządowych, prywatnych oraz szlacheckich oddziałach wyprawnych znacznie ponad 50 tys., może nawet blisko 100 tys. ludzi. Wartość tych sił zbrojnych była jednak niewielka. Z wyjątkiem nielicznych oddziałów komputowych i prywatnych, wojsko było słabo wyposażone i wyszkolone, źle zorganizowane i dowodzone, a przede wszystkim niezdyscyplinowane. Mimo charakteru wojny, skłaniającego do wzmożonego patriotycznego, czy też obywatelskiego wysiłku, żołnierzy cechowało niskie morale. Dotyczy to zwłaszcza stanowiących ok. 50\% armii oddziałów

110 T. Ciesielski, Armia koronna..., s. 539; idem, Agresja rosyjska..., s. 111.

111 T. Ciesielski, Dziatania zbrojne..., s. 186. 
wyprawnych. Z zachowanych źródeł wynika, że zarówno towarzysze, jak i pocztowi masowo opuszczali choragwie już po kilku tygodniach służby, także po przegranych i zwycięskich potyczkach. Częste były przypadki odmowy wykonywania rozkazów zaatakowania nieprzyjaciela, a nawet grożenia przełożonym, gdy ci upierali się przy podjęciu bardziej zdecydowanych działań zbrojnych. Takie wojsko nie było równorzędnym przeciwnikiem dla regularnych armii rosyjskiej i saskiej. Nieliczne sukcesy Polacy odnieśli tylko w potyczkach z wielokrotnie słabszym nieprzyjacielem i jego nieregularną jazdą ${ }^{12}$.

\section{Aneks}

Zachowały się nieliczne źródła przedstawiające stan obu armii Rzeczypospolitej w okresie bezpośrednio poprzedzającym śmierć Augusta II i, będącym jej następstwem, wybuchem polskiej wojny sukcesyjnej. Najbardziej znany jest obraz Jana Samuela Mocka przedstawiający kampament na polach pod Wilanowem (Czerniakowem) latem 1732 r., którego kopia znajduje się w zbiorach Muzeum Wojska Polskiego w Warszawie. $\mathrm{Na}$ pierwszym planie umieszczeni zostali na nim dobrze umundurowani żołnierze polskich regimentów pieszych i dragońskich, które uczestniczyły w tych kilkunastodniowych manewrach ${ }^{113}$. W rzeczywistości przed samym kampamentem jedynie dorekrutowano i doposażono istniejące oddziały, nie podnosząc wartości bojowej obu armii Rzeczypospolitej. Znakomicie wychwycił to pruski ambasador przy dworze polsko-saskim, Karol Gottfried Hoffman, który w zwięzłym raporcie przedstawiającym najważniejsze wy-

${ }^{112}$ Interesujące uwagi na temat wysiłku zbrojnego w latach 1733-1735: J. A. Gierowski, The Polish-Lithuanian Armies in the Confederations and Insurrections of the Eighteenth Century, [w:] War and Society in East Central Europe, t. II, eds. B. Király, G. E. othenberg, P. Sugar, New York 1982, s. 228-233. Jednoznacznie negatywna ocena wojsk polskich w: Ch. Mannstein, op. cit., s. 58-59 oraz А. П. Бутурлин, op. cit., s. 84.

113 SHD, GK, loc. 1956/2 oraz loc. 3645/5; „Kurier Polski” 1732, nr 138 i 139; BCz, 2632; J. Bartoszewicz, Kampament, passim; J. Benda, Kampamenty, passim. 
darzenia z 1732 roku i kondycję najwyższych instytucji Rzeczypospolitej, tak scharakteryzował armie koronną i litewską:

Fragment "Haupt Relation" za rok 1732 rezydenta pruskiego K.G. Hoffmana, Warszawa 22 I 1733, Geheimes Staatsarchiv Preussischer Kulturbesitz Berlin-Dahlem, I Hauptabteilung, Rep. 9: Polen, nr 27.60

"Bej der Pohlnische Armee ist keiner Voränderung vorgenommen worden, viel weniger einige augmentation geschehen, sondern es bestehet, die Crohn Armeè nach dem Comput in 12000. die Litthausche Armeè aber in 6000. Mann außer daß nach Maaßgebung der Grodnischen Constitution de AD 1726 von den verwilligten Regimentern aus den sogenandten Schultzen Huben, eins gerichtet worden, so unter dem Woywoden von Lublin ${ }^{114}$ stehet; Man könte fast mit beßerm Recht sagen, daß eine Verminderung der Pohlnische Armeè in diesem Jahre vogegangen, nachdem S.[eine] Königliche Maj.[estät] bej den Campement 2 neue Regimenter ausgesandt, so auf Sächsischen fuß und Sold stehen, auch an statt derjenigen 1200. Mann ${ }^{115}$, so der König hier halten dortt, dienste Thun sollen, welche leuthe aber mit der Zeit eintweder auseinandern oder wieder zu ihrem Alten Regimentern gehen dürfften, Wie Sie dann deswegen nur commandirte heißen wollen.

Die Artillerie ist in Pohlen in schlechkem Zustand, in Litthauen aber noch schlechkers, das hiesige Zeughauß, so in unserer Nachbarschafft stehet mehr zum Gebrauch des Feldzeugemeisters Aptiret, als daß man viel Gelegenheit zu dem Gewehr oder zu Gießhäußern und ammunition haben solte, wie dann die Republic auch wenig der zu hergiebt und was eingentlich zur Artillerie Verordnet ist, wohl meistentheils von dem Chef und den Subalternen verbraucht wird.

114 Jan Tarło, też generał lejtnant, szef regimentu pieszego tzw. łanowego.

115 Mowa o gwardii nadwornej, o której K. G. Hoffman napisał w innym miejscu, że w jej skład wchodziły „aus dem Printz-Gothaschen Regiment Grenadiers a Cheval, dem Nassauschen Regiment Dragoner, einem Commando vom Friesischen Corps, einigen Chevaliers Gardes und denen Grands Mousqvitairs". 
Die mir in der Republic Pohlen bekante festungen, sind Elbing, wo jetzo das Denhoffsche Regiment stehet, Thorn und Posen welches Graff Flemming mit seinem Regiment besetzet, Zamosc so eigentlich der Republic nichts anzehet, sondern vom Ordinat Zamoyski eintzig allein dependirt, eine sonst ziemlich reguliere fortification. Lemberg, vo der Commandant Tullian ist, Kaminiec worinnen der Obrist Schilling commandiret und Bielacerkiew and der Cosaquischen Gränzte, woselbst der Obriste v.[on] Göttchen mit einer Besatzung liegt."

\section{The Military Potential of Polish Army During the War of the Polish Succession (1733-1735). \\ Some Aspects}

(SUMmaRY)

In the paper I have presented military potential of Polish-Lithuanian Commonwealth in the 1730s. The army consisted of: Polish and Lithuanian regular troops of approximately 17-18 thousands soldiers with 300 cannons (cost annual ca $8640000 \mathrm{zł}=1075000$ thalers); royal guards -1200 soldiers; militia maintained by local government, cities, churches or even private person and the great myth - general levy. All of this troops were mobilized between 1733 and 1735 which resulted in 50 thousands (possibly even 100 thousands) soldiers under arms. It had a little military value due to lack of experience, poor equipment and low morale. In the results Polish and Lithuanian army were no match for regular armies of Russia and Saxony, which succeeded in plan of enthronement of August III Wettin.

Tomasz Ciesielski

Instytut Historii, Uniwersytet Opolski e-mail: ciesielski2@wp.pl 